\title{
THE ROUTINIZATION OF DEBT COLLECTION: AN ESSAY ON SOCIAL CHANGE AND CONFLICT IN THE COURTS
}

\author{
ROBERT A. KAGAN*
}

\begin{abstract}
In an era of supposed judicial imperialism, the decline of judicial involvement in an important policy area raises questions about the dynamics of legal change. In the past thirty-five years, despite large increases in the volume of loans and delinquent debts, there has been a sharp decline in contested debt cases in state supreme courts and an apparent decline in trial courts as well. In seeking an explanation, this article concludes that for both creditors and debtors, litigation has become more costly in relation to alternative courses of action such as renegotiating payment terms, declaring bankruptcy, or writing off unpaid debts. The attractiveness of nonlitigational alternatives is attributed to (a) the "legal rationalization" of credit transactions by institutional lenders, (b) increased litigation costs stemming from enhanced debtors' rights, and most importantly, (c) "systemic stabilization"-welfare state measures, economic regulation, insurance arrangements, and market diversification that facilitates the attenuation and spreading of financial losses.
\end{abstract}

In recent years, there have been a substantial number of historical studies of the dockets of American courts, stimulated in some cases by concerns that our society is becoming more litigious, in others by concerns that important kinds of grievances are left unadjudicated, and in still others by a sense that changes in the business of courts will provide insight into the dynamics of the legal system as a whole. There has been great interest in the apparent increase of certain types of court cases, such as product liability, malpractice, criminal procedure, and public law cases. These upsurges in litigation are sometimes taken as a sign that courts are at last dealing with injustices long neglected and sometimes as a sign that something is amiss in the social system if people and

* The research reflected in this article was supported in part by a grant from the National Science Foundation Program in Law and Social Science, Grant No. GS-384-13. Much thanks is due Terri Jennings for assembling and analyzing information concerning debt collection law and practice, and to Tom Jensen, Ed Rubin, Frank Munger, Bliss Cartwright, and Rick Lempert for their substantive and editorial advice. 
organizations more often resort to the courts to resolve their problems. Less attention has been given, however, to discovering precisely what kinds of social changes encourage or suppress particular kinds of litigation, and exactly how they do so. To stimulate further inquiry into those processes, this essay discusses the social, economic, political, and legal factors that have produced a recent decline in contested litigation in a significant sphere of court business-debt collection suits.

If the extension of credit is the lifeblood of a dynamic commercial society, the forcible collection of unpaid debts is its backbone. Governments, accordingly, have long been called upon to regulate the debt collection process-to provide authoritative decisions concerning precisely how much is owed and to whom, and to make the seizure and valuation of debtor's property a reasonably orderly process. Thus, historical studies repeatedly reveal the prominence of debt collection cases on the dockets of civil courts. Richard Kagan's examination of the courts of Toledo, Spain, in the sixteenth and seventeenth centuries found that "the most frequent source of lawsuits" were debts such as "unpaid rents, monies owed to a tax collector, the unpaid balance of a sale involving livestock" (Kagan, 1981: 85). At the appellate level, too, Kagan's sampling of the records of the Chancelleria at Valladolid (a major court of appeals) between 1540 and 1700 showed that "commercial contracts," the bulk of which can probably be characterized as debt collection cases, were the largest single category of cases, 20 to 25 percent of the total ${ }^{1}$ (Kagan, 1981: 110-11).

In eighteenth- and nineteenth-century American courts, debt collection cases also seem to have dominated the judicial process. Bruce Mann reports that in a six-month period in 1754 , a Windham, Connecticut, justice of the peace heard 47 actions on promissory notes, 4 debt actions on book accounts, and only 9 other kinds of cases (Mann, 1980: n. 31). Wayne McIntosh tells us that debt collection cases accounted for over 80 percent of civil cases filed in the St. Louis, Missouri, Circuit Court in 1820 (a depression year), over 50 percent in the 1820-1850 period, and over one-third (still the largest single type of case) in 1865-1895 (McIntosh, 1980-81: 829-30). Debt collection cases were similarly prominent in California trial courts in 1890 and 1910 (Friedman and Percival, 1976: 128), in Chippewa County,

1 This may be because appellants, even middle- and lower-class individuals battling nobles and merchants, had a fair chance of success. They won, on the average, between 25 and $30 \%$ of their appeals (Kagan, 1981: 101104). 
Wisconsin, between 1865 and 1894 (Laurent, 1959), and in the Boston Municipal Court and the Suffolk County Superior Court in 1880 and 1890 (Silverman, 1981).

While docketed cases usually reflect individual debtorcreditor disputes, the role of the courts in forcible debt collection occasionally boiled up into political conflict. The history of the Constitutional Convention in 1787 and the document it produced reflect fears of populist democracy sown by agrarian debtors' attacks against the courts, as in Shays' Rebellion in Massachusetts, and occasionally successful attempts by debtors to obtain legislation staying the collection of debts or making payment easier by obliging creditors to accept hastily printed (and fast-depreciating) paper money (Wood, 1969; Jensen, 1950: Chs. 15, 16; Parenti, 1980; McDonald, 1982). Similarly, the plight of agrarian debtors burdened by tight money and unyielding credit institutions was the fulcrum of widespread grass-roots political agitation and intense conflict over the gold standard during the Populist movement in the latter part of the nineteenth century (Goodwyn, 1978).

It should not be surprising, then, that even though most debt collection cases in the trial courts were settled or ended in uncontested default judgments, ${ }^{2}$ hard-fought debt cases also worked their way with considerable frequency up the judicial ladder to state supreme courts, which in the nineteenth century were often more active than legislatures as policymaking bodies. Debt cases accounted for almost 30 percent of the opinions of 16 representatively selected American state supreme courts in 1870 , and about 26 percent of their opinions in the 1870-1900 period (Kagan et al., 1977). ${ }^{3}$ Resolving conflicts and formulating rules of law concerning the debt collection process apparently absorbed more high court attention than any other type of legal or policy issue.

In the twentieth century, however, there has been a dramatic decline, both proportionately and in absolute

2 Mann reports that as debtors' obligations shifted from open-ended book accounts to formally executed promissory notes and bonds-a mark of dealings with creditors outside the debtor's community in an increasingly commercialized economy-most debt actions in Hartford and New Haven in 1750 "ended with the debtor's acknowledgment of indebtedness, confession of judgment, or default" (Mann, 1980: 207). In St. Louis, fewer than 30\% of debt collection cases between 1820 and 1925 involved contested judgments (McIntosh, 1980-81). See also Silverman, 1981: 135, 195.

3 Debt collection cases are defined to include not only lawsuits attempting to collect or prevent collection of loans, but also suits attempting to collect or prevent collection of moneys allegedly owed as a result of sales of property interests, goods and services (whether on an installment basis or not), court judgments, surety agreements, and suits among creditors for priority in payment from a debtor's assets. 
numbers, in debtor protection/creditors' rights opinions by state supreme courts, as indicated by Figure 1. The decline was gradual in the 1900-1935 period but has been dramatic since then. In the 1950-1970 period fewer than 7 percent of state supreme court (SSC) opinions involved debt collection matters; the $16 \mathrm{SSCs}$ in the Kagan et al. sample decided an estimated 170 debt cases per year, on the average, as contrasted with an estimated 886 per year in 1880-1900 and 717 in 19051925.4

Figure 1. Business Failure and Number of State Supreme Court Debt Case Opinions

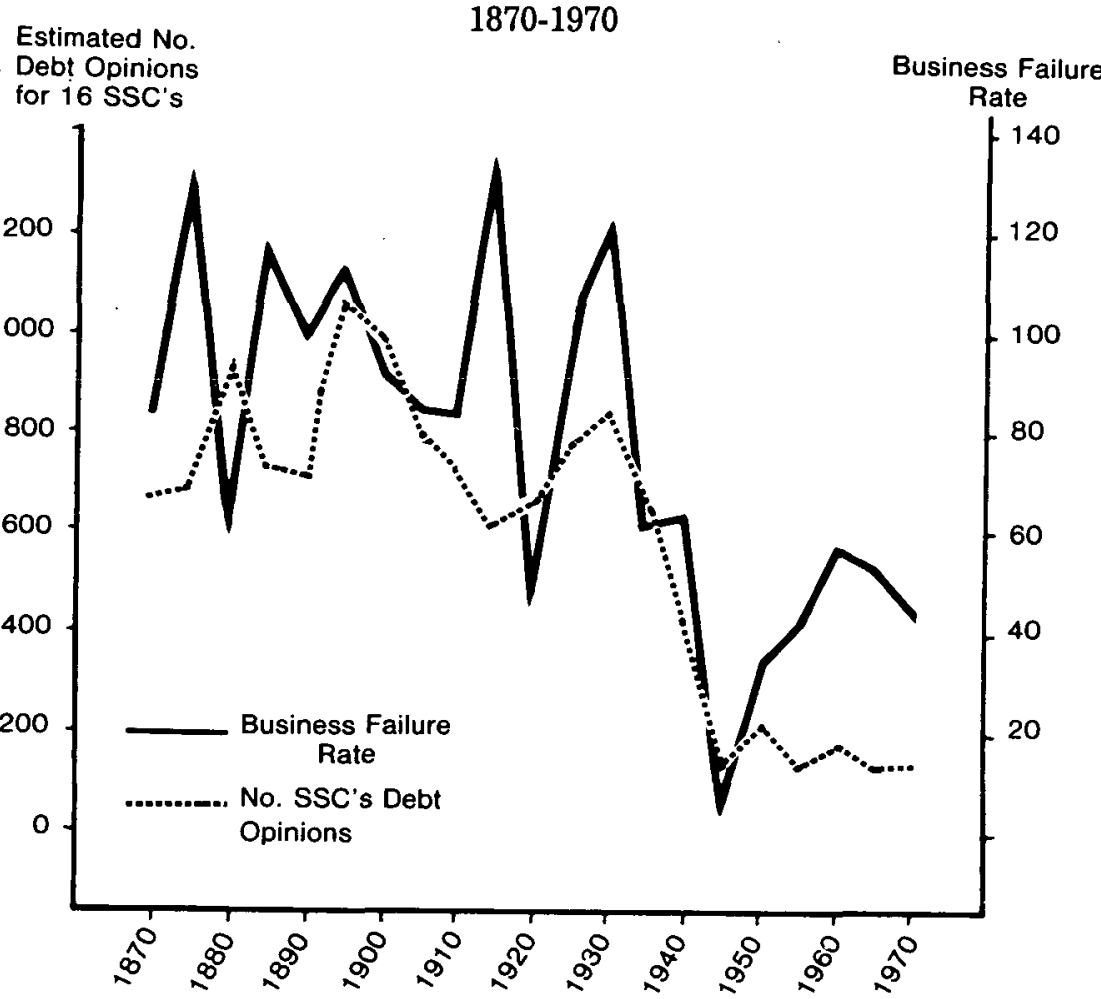

Business Failure Rate: no. failures per 10,000 enterprises listed by Dun \& Bradstreet

Estimated No. Debt Opinions: for 16 state supreme courts (Alabama, California, Idaho, Illinois, Kansas, Maine, Michigan, Minnesota, Nevada, New Jersey, North Carolina, Oregon, Rhode Island, South Dakota, Tennessee, West Virginia)

4 Baum et al. (1981-82) report an almost equally pronounced decline in the proportion of contract cases (many of which, I assume, could be classified as debt collection cases) and bankruptcy cases on the dockets of federal courts of appeals in the post-World War II era. Contract cases slumped from about $25 \%$ of 2 nd and 5 th Circuit cases in 1895-1930 to about $12 \%$ in 1960-1975, and from $20 \%$ of 9 th Circuit cases in 1895-1910 to $9 \%$ in 1960-1975. Business 
The gradual disappearance of debt collection cases from state supreme court dockets gives rise to both an historical and a theoretical puzzle. Why has a type of legal dispute so central to socioeconomic relations in a market economy and so often a focus of political conflict all but faded away as a subject for judicial policy-making? In an era in which, as the conventional wisdom has it, an "imperial judiciary" is intruding upon (or is being thrust into) ever-widening areas of economic and social life, why have high courts almost abandoned (or been permitted to neglect) debtor-creditor relations? These questions, in turn, relate to a persistent theoretical issue in the study of law and society: What determines the changing incidence of judicial involvement in a policy area?

To address these questions, this essay will examine available data concerning the volume of contested and uncontested cases in trial courts and will discuss five factors or trends that seem likely to affect the incidence of debt litigation: (1) fluctuations in the number or rate of problem-generating

Data for Figure 1

\begin{tabular}{|c|c|c|c|c|c|c|}
\hline $\begin{array}{c}\text { Sample } \\
\text { Year }\end{array}$ & $\begin{array}{l}\text { Average No. } \\
\text { Opinions } \\
\text { per SSC } \\
\end{array}$ & $\begin{array}{c}\text { Percent } \\
\text { Debt } \\
\text { Collection } \\
\end{array}$ & $\begin{array}{c}\text { Average } \\
\text { No. Debt } \\
\text { Opinions } \\
\text { per SSC } \\
\end{array}$ & $\begin{array}{c}\text { Estimated } \\
\text { Total Debt } \\
\text { Opinions, } \\
\text { 16 SSC's } \\
\end{array}$ & $\begin{array}{c}\text { Rate of } \\
\text { Business } \\
\text { Failures } \\
\text { @ 10,000 } \\
\text { Businesses } \\
\end{array}$ & $\begin{array}{c}\text { Total } \\
\text { Business } \\
\text { Failures } \\
\text { in U.S. } \\
\end{array}$ \\
\hline 1870 & 131 & 32.1 & 42 & 672 & 83 & 3,546 \\
\hline 1875 & 171 & 25.4 & 43 & 688 & 128 & 7,740 \\
\hline 1880 & 208 & 28.2 & 59 & 944 & 63 & 4,735 \\
\hline 1885 & 196 & 23.4 & 46 & 736 & 116 & 10,637 \\
\hline 1890 & 233 & 19.4 & 45 & 720 & 99 & 10,907 \\
\hline 1895 & 242 & 27.4 & 66 & 1056 & 112 & 13,197 \\
\hline 1900 & 240 & 25.3 & 61 & 976 & 92 & 10,774 \\
\hline 1905 & 213 & 23.6 & 50 & 800 & 85 & 11,520 \\
\hline 1910 & 245 & 18.4 & 45 & 720 & 84 & 12,652 \\
\hline 1915 & 292 & 13.2 & 39 & 624 & 133 & 22,156 \\
\hline 1920 & 228 & 18.1 & 41 & 656 & 48 & 8,881 \\
\hline 1925 & 254 & 19.4 & 49 & 784 & 100 & 21,214 \\
\hline 1930 & 270 & 19.8 & 53 & 848 & 122 & 26,355 \\
\hline 1935 & 215 & 18.8 & 40 & 640 & 62 & 12,244 \\
\hline 1940 & 184 & 14.9 & 27 & 432 & 63 & 13,619 \\
\hline 1945 & 119 & 5.9 & 7 & 112 & 4 & 809 \\
\hline 1950 & 160 & 9.0 & 14 & 224 & 34 & 9,162 \\
\hline 1955 & 158 & 5.6 & 9 & 144 & 42 & 10,969 \\
\hline 1960 & 172 & 6.9 & 12 & 192 & 57 & 15,445 \\
\hline 1965 & 182 & 4.9 & 9 & 144 & 53 & 13,514 \\
\hline 1970 & 167 & 5.2 & 9 & 144 & 44 & 10,748 \\
\hline
\end{tabular}

organization cases, about $80 \%$ of which, Baum et al. note, are bankruptcy matters, went from a high of $22 \%$ of 5 th Circuit cases in $1915-1930$ and $20.4 \%$ of 2nd Circuit cases in 1935-1955, to less than 5\% of Courts of Appeals cases in 1960-1975. 
events, i.e., debt repayment delinquencies and defaults; (2) litigation costs; (3) legal rationalization, i.e., trends toward the stabilization of legal rules and toward institutional contracting and collection processes designed to simplify or forestall litigation; (4) political conflict over existing legal rules and political demands for legal change; and (5) trends toward systemic stabilization, i.e., development of regulatory programs, public and private insurance and loss-spreading arrangements, and diversified economic institutions that prevent or deflect debtor-creditor conflict. Examining the limited evidence relevant to each of these factors will lead to an inductively constructed model that suggests how the various factors interact and that helps us understand the changing incidence of litigation in other areas as well. Moreover, the overriding importance of the developments discussed under the heading "Systemic Stabilization" in limiting debt collection litigation emphasizes the powerful role of collective welfare state measures and economic development in shaping modern legal action.

\section{PROBLEM-GENERATING EVENTS}

One obvious influence on the incidence of certain types of court cases might be the number of transactions or events in the surrounding society that can give rise to the kind of legal action in question. This "hypothesis" assumes that, over time, citizens and business organizations are inclined to take a relatively constant (even if small) proportion of their problems and disputes to court and to contest or appeal a relatively constant (even if small) proportion of those court cases. As potentially troublesome social and economic encounters or relationships take new forms or increase in number, one would expect the composition of court dockets to mirror, in a rough way, changes in the numbers of such conflict-producing transactions.

In some legal areas, this relationship seems to exist. Thus, the proportion of domestic relations cases on state supreme court dockets has tended to rise and fall with changes in the national divorce rate. State supreme court tort cases involving railroads declined in the twentieth century along with the steady reduction in the number of railroad accidents, while motor vehicle tort appeals rose as deaths from auto accidents increased (Kagan et al., 1977).

From this perspective, fluctuations in the incidence of nonpayment of debts should produce corresponding changes in 
debt collection litigation. One available proxy for the incidence of debt delinquency is the recorded data on national business failures. As Figure 1 and its accompanying data show, between 1870 and 1930, some upswings and some declines in business failures were paralleled by less extreme trends in the number of debt cases in state supreme courts, while at other times the two curves moved in opposite directions. Strikingly, however, the most drastic phase of the decline in debt case appeals, in the mid-1930s and 1940s, matched an equally dramatic drop in the rate and number of business failures. The dockets of some trial courts for which longitudinal data exist also seemed to reflect the business cycle, especially in the 1930s and ' $40 \mathrm{~s}$ :

-In Chippewa County, Wisconsin, debt cases, which numbered 407 (40 percent of the civil docket) in 19151924 , rose to 662 ( 55 percent of the civil docket) in the 1925-1934 period, which covered the depths of the Depression, only to decline to their earlier level after the holocaust of business failures and mortgage foreclosures of the early 1930s had run its course (Laurent, 1959).

-In Alameda County, California, my estimates from Friedman and Percival's published data indicate that debt case filings climbed from 236 in 1890 to 929 in 1910 and 1329 in 1930, a path that parallels the rate and absolute number of business failures nationwide for those years, and then declined to 853 cases in 1950 as prosperity returned and the business failure rate went down (Friedman and Percival, 1976).

But the post-World War II data tell a very different story. Between 1940 and 1970 (as Table I shows), farm loans, home mortgage loans, and corporate debt increased sixfold (far more than the rate of inflation), ${ }^{5}$ and consumer loans expanded by a factor of 16. Most of this mushrooming private debt, of course, is repaid on schedule and does not give rise to potential court cases. But defaulted and delinquent loans have undoubtedly increased in absolute numbers and amounts, probably in rough proportion to the increase in total debt. For example:

-If the delinquency rate for consumer debt held steady at its average level of 1.5 percent of outstanding loans (the bankers' rule of thumb, according to several

5 Corporate debt increased even more markedly in the 1970s. According to the editor of Coal Mining and Processing, while corporate debt has remained at roughly $38 \%$ of gross national product in the past 15 years, debt repayment costs, which represented $6 \%$ of nonfinancial corporations' cash flow in 1965 , accounted for about $\mathbf{2 8 \%}$ of cash flow in 1975 and far more, perhaps $50 \%$, in 1983 (Guccione, 1984). 
Table 1. Private Debt in Billions of Dollars as of End of Year

\begin{tabular}{|c|c|c|c|c|c|c|}
\hline & 1929 & 1940 & 1950 & 1960 & 1970 & 1976-78 \\
\hline $\begin{array}{l}\text { Corporate } \\
\text { Long-Term } \\
\text { Loans }\end{array}$ & $\$ 51.1$ & $\$ 43.7$ & $\$ 60.1$ & $\$ 139.1$ & $\$ 360.2$ & $\$ 568.8$ \\
\hline Farm Loans & $\$ 12.2$ & 9.1 & 12.3 & 25.1 & 58.7 & n.a. \\
\hline $\begin{array}{l}\text { Consumer Loans } \\
\text { Estimated* } \\
\text { Am't Delinquent }\end{array}$ & $\$ 7.1$ & 8.3 & 21.5 & 56.1 & $\begin{array}{r}127.2 \\
2.54 \\
\end{array}$ & 292.7 \\
\hline $\begin{array}{l}\text { Mortgage Loans } \\
\text { (1-4 family res.) }\end{array}$ & $\$ 18.0$ & 16.5 & 43.9 & 137.4 & 274.6 & 637.6 \\
\hline $\begin{array}{l}\text { Estimated** } \\
\text { Am't Delinquent }\end{array}$ & \$n.a. & n.a. & .9 & 3.65 & 8.9 & 28.7 \\
\hline
\end{tabular}

Source: Historical Statistics of the United States, 1975; B. Friedman, 1980: 30; Mortgage Bankers Association, 1980.

* Total amount delinquent estimated by using the following percentages: $1929,1940,1950,1960-1.5$ percent; 1970-2 percent; 1976-78-2.6 percent.

Source: Consumer Credit Leader, 1973.

* Total amount delinquent estimated by using the following percentages: $1956-2.08$ percent; $1960-2.66$ percent; $1970-3.24$ percent; $1977-$ 4.5 percent.

Source: Historical Statistics, 1975; Mortgage Bankers Association, 1981.

consumer loan officers I interviewed), delinquencies would have increased in amount from a total of $\$ 322$ million in 1950 to $\$ 2.4$ billion in 1973. (See also Moore and Klein, 1967.) In fact, the delinquency rate for consumer loans increased by at least 50 percent, beginning in the late $1960 \mathrm{~s}$, to 2.2 percent in 1973 and 2.6 percent in 1974. The gross dollar volume of new business reported by debt collection agencies to their trade association grew from $\$ 40$ million in 1965 to $\$ 93$ million in 1974 (American Collectors Ass'n, 1980).

- Home mortgage loans at least 30 days in arrears climbed from 2.08 percent of all loans at the end of 1955 to 3.06 percent in 1965 and 4.3 percent, twice the 1950 rate, in 1975. Nonfarm mortgage foreclosures, numbering about 23,000 nationwide in 1950, grew to about 50,000 in $1960,115,000$ in $1965,95,000$ in 1970 , and after the inflation and recession of recent years to about 175,000 in 1982 (Mortgage Bankers Association, 1981; Historical Statistics, 1975).

-The national business failure rate climbed from 4 per 10,000 enterprises in 1945 to 34 in 1950 and to 64 in 1961, averaging 51.4 throughout the $1960 \mathrm{~s}$. Absolute numbers of business failures also grew (Table 1). 
In sum, in the 1950s, 1960s, and 1970s, the incidence of individual and business "crises" that one would expect to lead to litigation over debts all increased dramatically. Nevertheless, debt collection cases continued to decline in the 1950 s and 1960s in absolute terms and as a proportion of state supreme court cases. Debt litigation in trial courts, too, does not seem to have increased proportionately, although the available data, shown in Table 2 , are scattered and far from adequate:

-In rapidly growing Alameda County, California, my estimates, based on Friedman and Percival's published data, indicate that the number of debt cases did grow from 853 in 1950 to 1511 in 1970 , but this growth barely exceeded population growth. ${ }^{6}$ In 1970 , there were 1.4 debt cases per 1000 county residents, compared with 1.2 in 1950 and the much higher rates of 3.8 in 1910 and 2.8 in 1930 (Friedman and Percival, 1976).

-McIntosh's (1980-81) published data on the St. Louis Circuit Court indicate that debt collection cases declined from their nineteenth-century highs to 15 percent of all civil cases filed in 1910, to less than 8 percent in 1940, and further to just under 5 percent in 1955 and 1970. Applying these percentages to the reported total cases yields an estimated 693 debt cases in 1940, 497 in 1955, and 477 in 1970. Thus, at least in this St. Louis court, the absolute number of debt cases filed throughout the 1940-1970 period actually declined.

Not only does the number of debt collection cases filed in trial courts in the post-World War II period seem to have fallen far short of the growth in business failures and loan delinquencies, but the number and rate of contested trial court debt cases declined, both absolutely and proportionately, in two of the three trial courts for which published data exist. (See Table 3.)

6 Most recent studies of courts have focused on the percentage of cases allocated to different areas of law over time. This paper is more concerned with trends in absolute numbers of cases. In using published studies, especially those based on samples of cases, I have had to estimate the total volume of debt cases by applying the percentage of debt cases in the sample to the total volume of decisions in the same period (which proved possible only when the latter figure was published). It is not clear, from Friedman and Percival's published data, to what extent the increase from 1950 to 1970 actually involved debt collection cases. There was a decline in actions on promissory notes but a major increase in cases coded "other contracts and debts," some (or many) of which may not have been basically debt matters. In San Benito County, California, there was a decrease in contract cases and in "other contract and debt" between 1950 and 1970, suggesting that the results I have reported for Alameda County may inflate "debt cases" in 1970. 


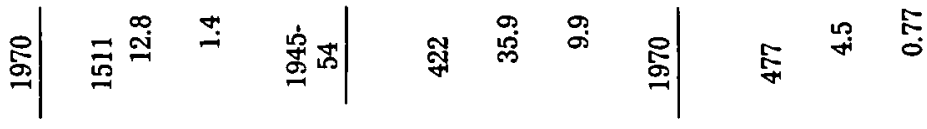

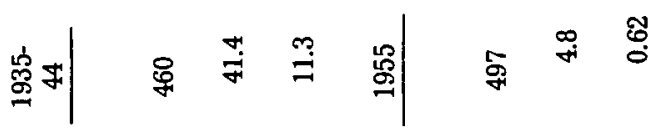

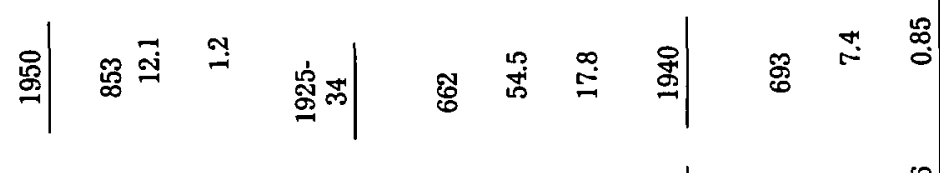

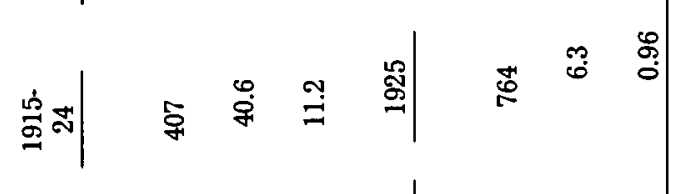
岁む ஜำ 岁兽 䓢

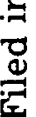

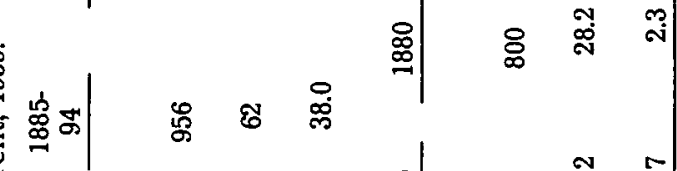
峁

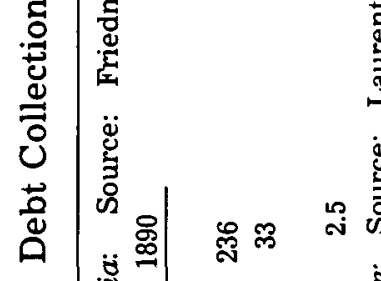
认゙

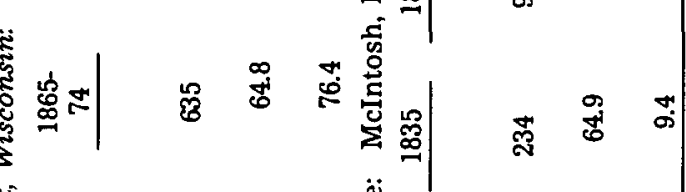
势

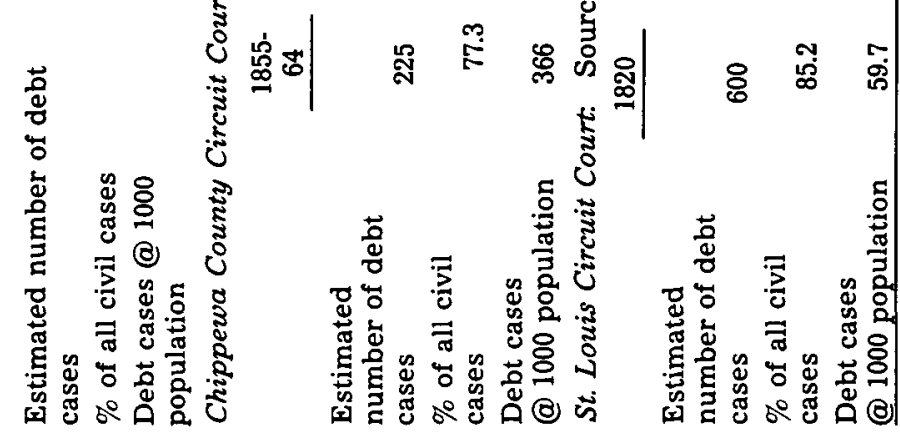


-Laurent's (1959) data from the Chippewa County, Wisconsin, Circuit Court indicate that in contract cases (the overwhelming majority of which were debt collection matters) the proportion that apparently was contested fluctuated between 17 and 30 percent in the decades between 1865 and 1944, with no clear trend toward lower rates. Yet in 1945-1954, the last decade covered by the study, only 10 percent of debt cases were contested, the lowest rate in the century.

-Another measure of the incidence of strongly asserted legal defenses is the percentage of cases resulting in judgment for defendants. Here, too, the Chippewa County data show no clear trend between 1865 and 1944; defendants hit their peak victory rate in 1905-1914, winning contested judgments in 10.5 percent of contract cases, but then slipped back in the 1915-1944 period to the historically average rate of 4.3 to 6.1 percent. Once again, however, in 1945-1954, at the outset of the post-World War II era, defendant victories in contested contract cases declined to an historical low, a mere 1.5 percent of the cases.

-McIntosh's (1980-81) St. Louis Circuit Court data indicate that the proportion of debt cases resulting in contested hearings and judgments was a steady 25 to 28 percent in 1820-1850, 1865-1895, and 1910-1925. Defendants won contested judgments in only about 5 or 6 percent of cases in each of those periods. In St. Louis, too, the post-World War II period reflects a sharp decline in contested cases, to about 10 percent of debt collection cases in the 1940-1970 period, and a decline in victories for defendants via contested judgments to 2.4 percent of cases.

-In Alameda County, California, according to Friedman and Percival's (1976) data, the percentage of contract cases going to trial decreased from 30.3 percent in 1890 to 22.6 percent in 1912 but leapt upward to 57.1 percent in 1930. As in Chippewa County and St. Louis, the percent of cases tried in 1950 declined (to 19 percent) but jumped up to 27 percent in 1970, apparently counter to the trend in St. Louis.

One possibility, which Friedman and Percival (1976) suggest, is that debt collection matters have been diverted to municipal and small claims courts. This suggestion is consistent with studies of contemporary municipal courts (Wanner, 1974) and small claims courts (Ruhnka et al., 1978; Pagter et al., 1964; Small Claims Court Study Group, 1972) which show that their dockets are dominated by debt collection cases. While time series studies of small claims court dockets 


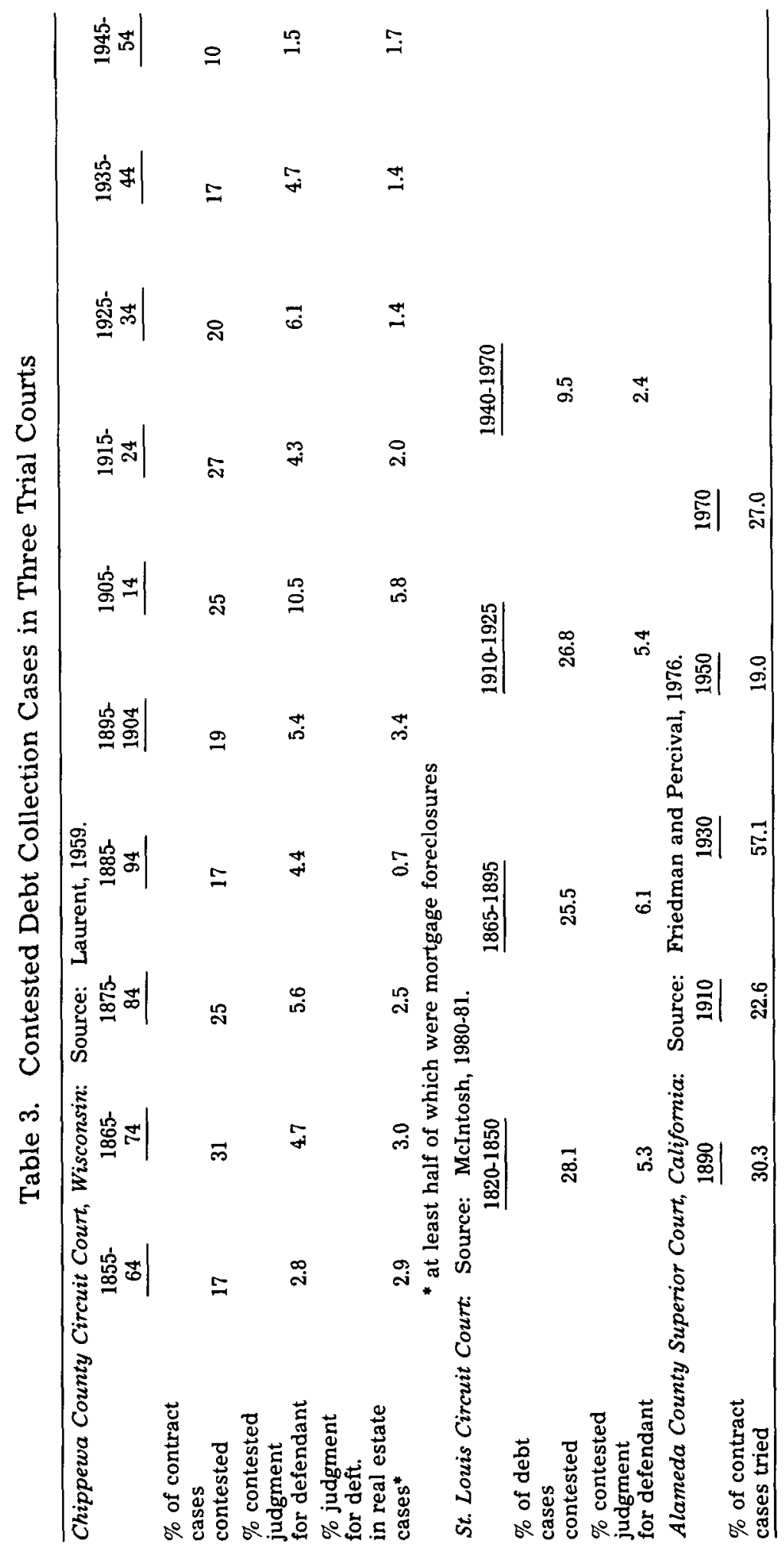


are lacking, my estimates based on data from California, presented in Table 4, indicate substantial growth in the number of debt collection cases in municipal and small claims courts.? However, in the municipal courts, at least until 1980, debt cases did not increase more rapidly than the state's population. And in neither the municipal nor the small claims courts did collection cases grow as rapidly as the national debt delinquency totals shown in Table 1. Moreover, the ability of litigants to sue on small debts in small claims courts (the maximum jurisdictional amount in California was increased from $\$ 500$ to $\$ 750$ in 1977 and is now $\$ 1500$ ) does not explain why debt collection cases arising from the mounting numbers of larger debts (mobile home loans, home mortgages, small business loans, corporate loans) have not increased in trial courts of general jurisdiction and have almost disappeared from state supreme courts. Thus, increased litigation in small claims courts accounts, at best, for only a small part of the decline in debt litigation in the general trial courts and courts of appeal.

\section{LITIGATION COSTS}

In discussing the linkage between problem-generating events (in this case, delinquencies in repayment) and litigation, I assumed that only "some proportion" of delinquencies would lead to declared defaults, and that only some (constant) proportion of defaults would end in collection suits. The "constant proportion" assumption is obviously too simplistic. Consider, for example, the likely impact on litigation volume of changes in the cost of litigation. Creditors are often deterred from bringing suit by the costs of hiring attorneys, enduring court delays, gaining the cooperation of sheriffs in serving process and executing judgments, and so on. Litigation costs, including opportunity costs such as taking time off work to appear in court, undoubtedly lead some debtors not to contest suits they think unfounded (Caplovitz,

7 California's Administrative Office of the Courts does not report debt or contract cases as a separate category. For the municipal court figure, I relied upon the proportion of debt cases shown in Wanner's study of municipal court filings in Baltimore, Cleveland, and Milwaukee (1974). Studies indicate that the proportion of small claims filings that involve debt collection matters is quite variable, ranging from 40 to as high as $80 \%$. However, the Ruhnka study of 15 small claims courts in 14 states (1978) found that an average of $65 \%$ of all filings involved debt collection. The corresponding figure for the Pagter study of the Oakland-Piedmont-Emeryville small claims court in California (1964) was $58 \%$. I used the $65 \%$ figure. 


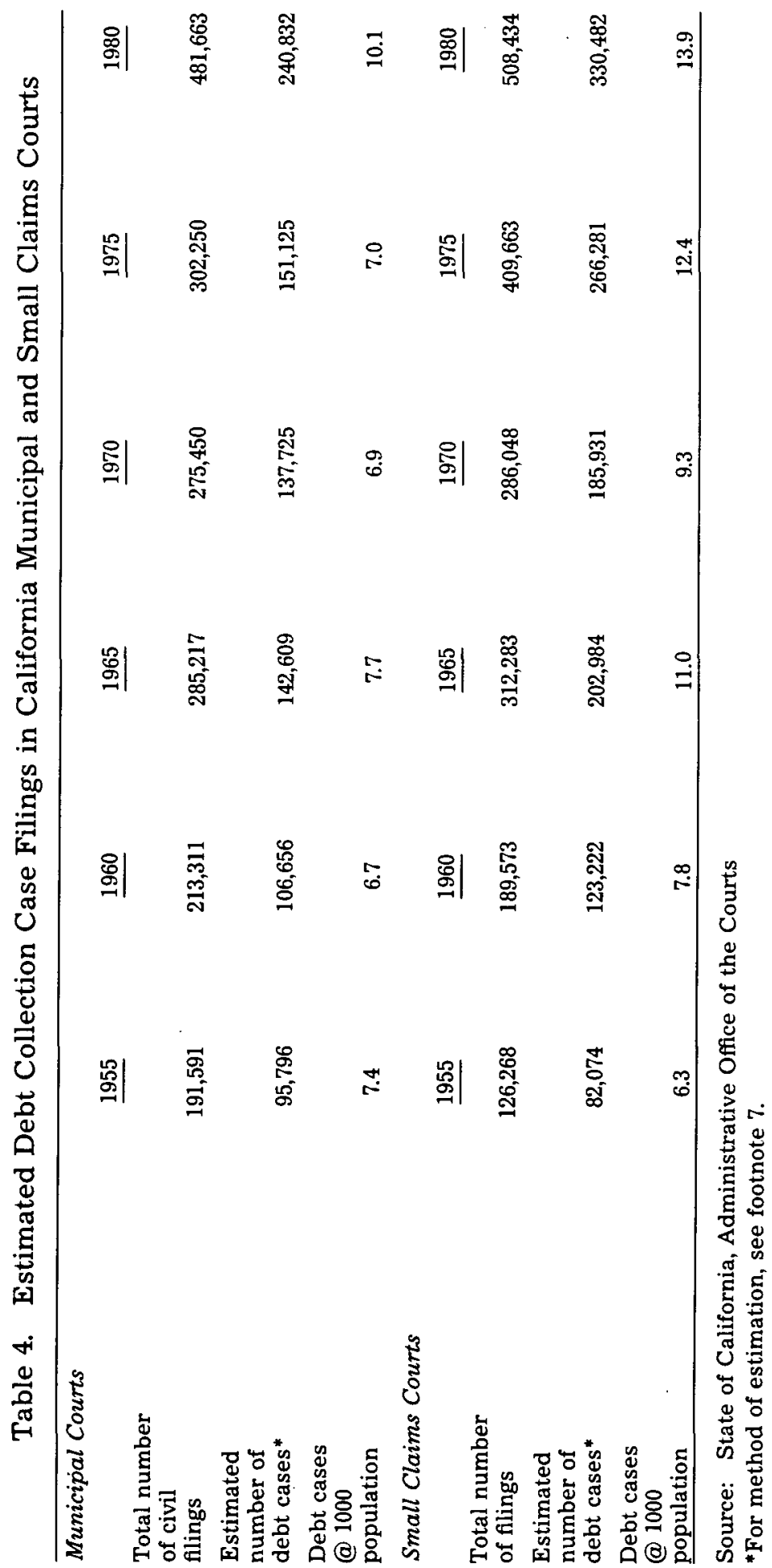


1974). Hence, court dockets might be expected to reflect only that subset of delinquencies or defaults in which the amount at issue exceeds the various costs of litigation, tangible and intangible. If so, court cases could be expected to decline, or to rise more sluggishly than problem-generating events, during periods in which the transaction costs associated with litigation are rising, either absolutely or in relation to the average amount at issue.

For example, one explanation for the post-World War II decline in debt cases in state supreme courts might be that during this period many states created a layer of intermediate appellate courts between trial courts and the supreme court, thus increasing the cost, in time, uncertainty, and attorneys' fees, of pursuing matters to the supreme court. This explanation would predict that the post-1945 fall-off in supreme court debt opinions would be sharper in states with intermediate appellate courts than in those without them. However, the prediction, and hence the explanation, does not hold, for the debt case decline was virtually as great in one group of states as in the others ${ }^{8}$ (see Kagan et al., 1978: 989).

The impact of litigation costs on the incidence of debt cases, and especially of contested cases, may be more evident at the trial court level. Because a larger proportion of credit now involves small consumer loans (see Table 1), the average amount at stake in a loan default may be less financially significant to the parties than was the case in earlier eras when proportionately more loans were for the purchase of real estate, farm needs, and commercial goods and facilities, and lenders were less likely to be large financial institutions. In consequence, today's debtors and creditors faced with potential court cases may be more likely to absorb their losses rather than litigate or appeal (Felstiner, 1974).

Unfortunately, I have encountered no systematic evidence concerning the average amount of all debts, either in society at large or in the courts, today or in times past. And despite the general impression that court calendars today entail longer

8 A related hypothesis might be that the fall-off in supreme court debt cases in states with intermediate appellate courts was due not to the costs of appeal but to a facet of judicial culture: in states with intermediate appeals courts, the supreme court usually has discretion to hear or reject petitions for review, and high court judges, preoccupied with criminal and constitutional matters, simply did not want to hear debt cases. The equal decline of debt cases in supreme courts without discretion undercuts this hypothesis, however, as do scattered expressions of opinion by appellate court judges that they would rather hear more commercial cases and fewer criminal cases (see Kagan et al., 1978: 981). 
delays and that trials and pre-trial discovery proceedings are more expensive, I know of no studies that show that litigation expenses have in fact increased in relation to GNP per capita or some other meaningful baseline. It is undoubtedly true, of course, that credit cards and installment sales have generated vast numbers of smaller debts. In 1972 the average amount of the $1,210,000$ "small loans" by California finance companies was $\$ 1069$, indicating that most were under $\$ 1000$ (California Department of Corporations, 1981); the average amount of the defaulted small loan, assuming some pay-back of principal, undoubtedly was even smaller. The average account handed over to debt collection agencies was only $\$ 55$ in $1965, \$ 90$ in 1975 , and $\$ 130$ in 1980 (American Collectors Association, 1980: 14). Even given the existence of institutions like small claims courts that are expressly designed to reduce legal transaction costs when little money is at stake, many unpaid debts are probably not worth litigating. In California and other states that preclude debt collection agencies from using small claims courts, the point at which it pays to institute suit or to contest will reflect the fact that collection agencies must employ attorneys and use municipal courts, as must debtors inclined to resist. 9 Hence, one would not expect small claims litigation to rise quite as rapidly as small debt delinquencies.

Nevertheless, the fact that litigation costs may deter lawsuits over small consumer debt delinquencies does not in itself explain the drop in debt collection cases in state supreme courts and in trial courts of general jurisdiction. As noted earlier, there has been a rapid increase in substantial loansreal estate mortgages, commercial and corporate loans-as well as increases in the annual numbers of mortgage defaults and business failures. The average amount of liabilities involved in business failures rose steadily, from $\$ 44,700$ in 1948 to $\$ 175,000$ in 1970 (U.S. Commission on the Bankruptcy Laws, 1973: 35). Many consumer loans, moreover, are for amounts seemingly worth litigating about. In 1972, the average loan on a new car

9 California collection agencies, the president of their trade association recently estimated, take no more than $20 \%$ of their cases to court, largely bacause of litigation expenses and delays. Unless the loan agreement in default contains a provision obligating the debtor to pay the collection company's attorney's fees, the collection agency must pay its attorney a retainer in advance. The fee averages 20 to $25 \%$ of the money the attorney collects. In addition, the collection agency must lay out money in advance for court filing fees and sheriffs' fees for service of process. Given delays in crowded municipal courts, sheriffs' policies of not forwarding garnished wages to the collection agency until 90 days after execution, and the possibility that sherifis will fail to collect the judgment at all, credit agencies often conclude that bringing suit is not financially worthwhile for small debts. 
was $\$ 3378$ (Bender, 1974). In 1980 , debt consolidation loans by California's small loan finance companies (the most common type of finance company loan) averaged almost $\$ 2300 .^{10}$ Hence, the post-World War II decline in debt litigation and appeals has occurred in the face of an increase in delinquent debts ostensibly large enough, in many cases, to exceed the direct litigation costs, such as attorneys' fees, that would be involved in collecting or contesting them.

It is impossible to reject the notion, however, that increased litigation costs, defined more broadly, have been an important factor in declining litigation rates. The issue is whether all the costs incurred by creditors and debtors in the litigation and appeal process-including the diversion of time and effort from other concerns, delay, the aggravation and anxiety associated with lawsuits and formal execution, damage to reputation-have made litigation over delinquent debts increasingly less attractive than alternative courses of action, such as extracting consensual repayment agreements, arranging refinancing, commercial arbitration, or in the case of the debtor simply conceding liability and in the case of the creditor giving in to debtors' excuses or legal defenses, and trying to recoup losses in other ways. Succeeding sections explore such influences on the relative costliness of litigation, first by examining legal changes that may have affected the availability of viable defenses and then by examining, under the head of "Systemic Stabilization," measures that may have made forbearance or "giving up" more feasible.

\section{LEGAL RATIONALIZATION}

According to one commonly held view of modern life, human and economic affairs are becoming increasingly subjected to rational legal rules and procedures designed to deal with recurrent kinds of problems. If so, the more complete and settled the law, the more one would expect "failed" transactions, accidents, and disputes to be perceived as having clear legal consequences, and the less the likelihood they would lead to contested court cases. Court dockets, then, would be expected to change in response to the social creation of new problems as the law attempts to "catch up." Thus, debt

10 California small loan companies in 1981 issued 81,000 "consolidation" loans. Other leading categories were loans for auto purchases (58,000 loans; average amount $\$ 3467$ ), vacations and holiday expenses $(48,000$; average $\$ 1630)$, household furnishings $(23,000 ; \$ 1606)$, expenses of accident or illness $(15,000$; $\$ 1589)$, tax payments $(7,900 ; \$ 2179)$, and school expenses $(5,700 ; \$ 2111)$ (California Department of Corporations, 1981: 15). 
collection cases might well be prevalent in a rapidly growing and changing economy whose credit system was still struggling to achieve stability (as in the latter part of the nineteenth century). However, with the development of a mature commercial society, debt collection cases should become "old problems" covered by a comprehensive set of rules and precedents, and contested cases and appeals should fade from court dockets, except when radically new forms of credit and security arrangements arise.

Legal rationalization of this sort also implies the development of more efficient modes of adjudication. The institution and expansion of federal bankruptcy procedures, beginning with the Act of 1898 , can be viewed as an example. At least one-third and probably more than half of the debt collection cases in state supreme courts in the late nineteenth and early twentieth centuries arose from situations in which a debtor's default visited loss or liability on a whole network of individuals or business firms that had dealt with him-creditors who had lent him money, sureties who had vouched for him, and innocents who had purchased his property without knowing of liens upon it. As an example of the complexities that follow defaults, consider the not unusual situation of a company that is unable to pay for a new building. Immediately, the question arises of who should have priority in payment from the company's remaining assets-the construction company (pursuant to a mechanic's lien), suppliers of lumber and plumbing fixtures (pursuant to materialmen's liens), or the bank that had financed construction (secured by a mortgage on the real estate). ${ }^{11}$ State supreme courts were continually asked to resolve such conflicts among creditors.

Federal bankruptcy procedure, as first established in 1898 and expanded in 1910 to include voluntary filings by corporations, can be seen as an attempt to rationalize the problem of treating competing claimants fairly. State law created incentives for each creditor to rush to the courthouse to win a priority-establishing, winner-take-all judgment, even though such individualistic remedies might lead, as one legal scholar put it, "to a piecemeal dismantling of a debtor's business by the untimely removal of necessary operating assets" (Jackson, 1982: 864). Federal bankruptcy sought to establish a collective system that marshals the debtor's assets, allocates them among all creditors according to a set scheme of

11 See, e.g., Cummings et al. v. Consolidated Mineral Water Co. and Industrial Trust Co. 
entitlements and priorities, and thereby "provides a framework for implementing a consensual collective proceeding," either under the supervision of a trustee or outside the bankruptcy process (Jackson, 1982: 867). ${ }^{12}$

The idea of legal rationalization also implies that in dealing with the complexities of modern legal systems, organizations and individuals increasingly will rely on lawyers and other specialists to handle problems and disputes. Legal specialists characteristically process and settle typical cases in lawregarding ways, but they do so informally, without judicial involvement. Thus, the growth of professional police departments, prosecutors' offices, and public defender offices should lower the proportion of criminal arrests that eventuate in trials (L. Friedman, 1973). Claims adjustment offices in liability insurance companies (Ross, 1970) should keep automobile tort litigation from increasing as rapidly as the number of accidents.

With respect to debt collection, one would expect contemporary sheriffs to be less prone to the legal errors and corruption that in the late nineteenth and early twentieth century often led to cases protesting the judgment collection and execution sale processes. ${ }^{13}$ One would also expect modern lending institutions to develop ways of forestalling expensive court contests over unpaid debts. As early as the eighteenth century, merchants began to insist that extensions of credit be memorialized in written promissory notes with clearly stated terms. This tended to foreclose court hearings in which equitable aspects of the underlying transaction would be contested (Mann, 1980). In his study of Boston courts in 1880 and 1900, Robert Silverman noted:

The law of debt based on negotiable instruments and other commercial documents was better defined than was tort law in the late nineteenth century. Plaintiffs normally presented documents to substantiate their

12 Although the Bankruptcy Act generally preserved state-created creditors' rights as factors affecting priorities in federal bankruptcy proceedings, periodic amendments to the Bankruptcy Act gradually extended federal jurisdiction and rulings to more aspects of debtor-creditor and intracreditor relationships, which presumably would reduce the incidence of individual collection suits in state courts. To take a recent example, before 1971 a creditor could nullify a debtor's discharge of a debt in federal bankruptcy by showing that the debtor had engaged in acts of fraud in inducing the extension of credit; to do so, creditors had to sue and prove fraud in state courts. This was attempted, according to one estimate, in 18 to $20 \%$ of personal bankruptcy filings. After the federal law was changed so that the fraud exception had to be claimed in federal bankruptcy court, the frequency of such claims was cut roughly in half (Shuchman, 1977: 81).

13 See, e.g., Pearce v. Maguire, County v. Brock et al. 
claims. A properly executed promissory note or other instrument of indebtedness made the calling of many witnesses unnecessary and also made it easier to determine the amount owed. Most debt actions were open-and-shut affairs in which defendants did not contest plaintiffs' demands (Silverman, 1981: 135).

In the modern economy, as credit becomes dominated to an increasing extent by large, bureaucratized, legally sophisticated institutions such as banks, multi-state finance companies, and department stores, loan agreements contain standardized language designed to cover virtually every conceivable kind of contingency or dispute, thereby foreclosing possible legal defenses by debtors and competing creditors. Corporate loan agreements now run for pages, articulating the priority of liens to be imposed on the debtor's property or accounts receivable, clarifying the nature and valuation of collateral, and specifying the characteristics of financial reports that are to be submitted by the debtor at periodic intervals. Increasing recourse to bankruptcy by insolvent business firms has encouraged institutional lenders to insist on specific security arrangements that accord secured creditors priority under the law or entitle them to assert their rights before default (Miller, 1977: 44; Gessner et al., 1978). Today, a large proportion of loans by financial institutions to small businesses are secured (Shuchman, 1977: 95). In consumer credit, as early as the mid-nineteenth century merchants developed conditional sales agreements that in the event of default entitled creditors to repossess and resell consumer durables without first going to court. It was also common to require borrowers to sign "confessions of judgment" or wage assignments that in the event of nonpayment enabled the creditor to obtain a judgment or garnish the debtor's wages without notice and without filing suit, until this practice was banned about twenty years ago as a violation of due process. To forestall litigation, contracts among business firms for the supply of goods and services now almost routinely include provisions for binding arbitration of disputes concerning the justifiability of nonpayment (see Bonn, 1972).

More sophisticated credit information systems also help prevent legal problems and litigation over bad debts. By obtaining independent appraisals, title searches, and audited financial statements, banks evaluate their security interests before lending, thus minimizing the need to sue for deficiency judgments in the event of default and preventing disputes with other creditors. At the turn of the century, credit reference 
agencies were unreliable (Silverman, 1981: 153). Today, lenders subscribe to interstate services that compile and update credit histories on business and individual borrowers. Some banks now assign numerical credit ratings to individual loan applicants based on the borrower's particular "credit profile," which is calculated by comparing the applicant's financial characteristics with the bank's computerized analysis of the correlates of successful and unsuccessful loans. Consequently, a threat to impair a delinquent debtor's credit rating is often a more credible and effective collection tactic than is a lawsuit (see Leff, 1970).

To the extent that these trends toward legal rationalization are strong and pervasive, one would expect a declining proportion of defaulted loans to result in court cases. A growing proportion of court filings, moreover, would not signify real legal disputes, but would be filed to obtain an uncontested court order authorizing seizure and sale of the debtor's property, or to establish the creditor's legal priority over laterfiling creditors. From this perspective, one might argue that appeals to state supreme courts in debt cases have become less frequent because the law has become settled, inter-creditor conflicts have been drawn into federal bankruptcy proceedings, precedents and carefully drafted agreements cover and resolve most disputes, and, in the growing number of state supreme courts with discretion to select cases on the basis of "importance" (Kagan et al., 1978), the judges are more concerned with new issues than with the complexities of old debtor-creditor law issues.

Some of the available evidence seems to support the legal rationalization hypothesis. In the federal courts, bankruptcy filings increased spectacularly from about 10,000 per year in 1946 to 250,000 in 1975. But the proportion (and perhaps the absolute number) of debt-related "contract" and "business organization" cases in federal Courts of Appeals declined (Baum et al., 1981-82), suggesting that the bankruptcy process was relatively successful in "settling" the claims of competing creditors in a consensual or routine way. ${ }^{14}$ Yet it seems unlikely that the marked decline in state supreme court debt cases after the mid-1930s can be explained by the sudden transformation of the law of debtors' and creditors' rights,

14 It should be noted, however, that in most bankruptcy proceedings the bankrupt does not have enough assets left for competing unsecured creditors to fight over (Stanley and Girth, 1971). An interesting question, on which I did not attempt to gather data, is whether the rate of contested legal issues within bankruptcy proceedings, however low, has decreased. 
which had figured in so many appellate cases between 1870 and 1930 , into settled doctrine. In fact, as will be shown in the next section, this body of law has, if anything, become more turbulent in recent years.

At the trial court level, as I noted earlier, debt case filings had begun to decline in proportion to population growth by 1900 , and this trend continued, with perhaps an interruption at the outset of the Great Depression, through 1970 (Table 2). This seems consistent with the idea that the legal process became increasingly rationalized as lenders became increasingly adept at devising loan agreements and security arrangements to forestall legal conflict and at routinizing nonjudicial debt collection procedures. On the other hand, from the mid-nineteenth century until after World War II, there was no consistent downward trend in the percentage or number of contested trial court cases or in the already small percentage of judgments for defendants (Table 3 ), which suggests that in those years the rationalization process was not increasingly effective in suppressing legal conflict. ${ }^{15}$

Why would declines in contested debt cases both at the trial court and state supreme court level show up only in the post-World War II period? One possibility, consistent with the legal rationalization hypothesis, is that federal bankruptcy, a primary device for "rationalizing" complex debt collection cases, reached its full jurisdictional and remedial range only after statutory amendments in 1938 and the post-World War II period. Not until the 1950s did annual numbers of business bankruptcy cases grow as rapidly as annual business failures, suggesting that only then did federal bankruptcy become a routine rather than an exceptional forum for resolving the claims of competing creditors. This explanation seems inadequate, however, because bankruptcy filings have not been sufficiently numerous to "absorb" more than a small proportion of state court debt cases and potential appeals. ${ }^{16} \mathrm{~A}$ second

15 Richard Lempert has suggested that as a smaller proportion of debt defaults was pursued in court, the subsample of flled cases might be expected to involve a rising, or at least a steady, proportion of highly disputed issues. This has not been true, however, of the post-World War II era.

16 The $\$ 2$ billion in debt discharged in bankruptcy in 1968 represented about $0.2 \%$ of private debt outstanding (Stanley and Girth, 1971: 40) and probably a small proportion of loans in default, which averaged $1.5 \%$ of outstanding consumer debt. See Table 1, supra. In California, in 1980, I estimate a total of about 80,000 debt case filings in superior courts, and 240,000 smaller cases in municipal courts. Extrapolating these figures to the nation as a whole, based on the California: U.S. population ratio, I estimate about 800,000 debt cases and 2,400,000 smaller debt cases, figures that far exceed the 450,000 federal bankruptcy cases. 
possibility, to be discussed in detail later, is that bureaucratized lending institutions did not really dominate a large proportion of the credit market until recent decades. This possibility suggests that the most fundamental causes of declining debt litigation lie not in the law but in fundamental changes in the economic and social system. Before discussing those systemic changes, however, another set of factors that seems to conflict, at least in part, with trends toward legal rationalization should be examined.

\section{POLITICAL CONFLICT}

The notion that the law will gradually become "rationalized" and "settled" as potential disputes are shortcircuited by carefully drafted legal documents and routinized procedures assumes that the losers in this process accept the existing law and contractual arrangements as the sole and legitimate measure of what they are entitled to complain about (see Felstiner et al., 1980-81). It assumes, too, that the law will inevitably be shaped to reflect the "efficient" ways of doing business favored by large, impersonal, "economically rational" corporate enterprises.

Arguments for economic efficiency and the preferences of business elites certainly carry weight in the legal process. However, American politics has long had a populistic, antimoneyed-interests strain as well. Every legal rule has obvious distributive aspects as well as a relationship to economic efficiency, and every creditor's right may be experienced as a noose around the debtor's neck. Many debtors sense that they are being "ripped off" and some complain about it. Disputes between creditors and debtors are thus more than problems of commercial relations; they reflect politically important social cleavages. Politicians sometimes find it to their advantage to champion the interests of the many debtors in their constituencies against the impersonal practices of banks and merchants, and the well-organized interests that speak in the name of economic rationality or legal certainty do not necessarily prevail in the legislative arena. From this perspective, the law-on-the-books usually is no more than a temporary battle line in a never-ending political struggle between lenders and debtors, and one would expect debt litigation (and/or legislative activity on the subject) to increase whenever debtors or creditors as a politically organized "class" are actively seeking to change or reject the legal status quo. 
A look at the numerous debt opinions written by state supreme courts in the late nineteenth century suggests that these courts were indeed being used as a political resource for escaping the strictures of rationalized rules and procedures. Debt cases were often complex, involving conflicts between debtors and multiple creditors, guarantors, and innocent purchasers of lien-encumbered property. Precise "legal" answers, based on the detailed body of rules concerning priority of liens and execution procedures, were often available. These rules, however, frequently worked to the disadvantage of less sophisticated borrowers and lenders, who then appealed to the high courts, asking the judges, in effect, to reinterpret the language of contracts and precedent and render decisions that were equitable under the circumstances. ${ }^{17}$ Appellants argued that the creditor's document misstated the "true" agreement, or that property that the debtor had conveyed to relatives should be held subject to a "constructive" lien. Because appellate court judges were often willing, in Martin Shapiro's evocative phrase, to "keep clawing their way back toward the facts" (Shapiro, 1975: 352), to balance political and equitable considerations against efficiency-enhancing impersonal legal rules, debt cases kept coming to the SSCs.

Debtors have periodically turned to legislatures, too, in their efforts to mitigate the legalistic enforcement of "settled" creditors' rights. Periods of deflation and recession (including the recent one) typically stimulate legislative action to restrict foreclosures, or to modify the process for the sale of repossessed property. Periodically, legislatures have expanded the amounts and kinds of debtor property that must be exempted from the execution of judgments (Vukowich, 1974). As a result of the "consumer movement" of recent years, the law of debtor-creditor relations, far from becoming more "settled," has changed rapidly. For example, the Uniform Commercial Code, adopted by most states in the 1960s, affirmed and enhanced the power of courts, increasingly suspicious of "contracts of adhesion," to refuse to enforce "unconscionable" provisions concerning sales of goods (UCC § 2-302), and to decline to compel payment on a contract when an "implied" warranty of merchantable quality is found to have been breached. ${ }^{18}$ State and federal courts and legislatures banned

17 See, e.g., First National Bank of Pocatello v. Bunting and Co., St. Louis Hoop and Stove v. Dansforth and Wife, Lennon v. Parker.

18 More recently, breach of warranty defenses were further expanded by the federal Magnuson-Moss Warranty Act (1975) and by a 1976 Federal Trade Commission rule that in effect abolished the holder in due course doctrine, 
various agreements and procedures that had enabled creditors to seize or repossess consumer-debtors' property, or to garnish their wages, without first having to give notice and to go to court. ${ }^{19}$ In addition, the federal Consumer Credit Protection Act of 1968 restricted the proportion of debtors' wages that can be seized via garnishments, and a number of state legislatures granted debtors protection from deficiency judgments after the sale of secured property (Schwartz, 1983: 123). The federal Fair Debt Collection Practices Act (1977), following some state measures, banned harassment by collection agencies and expanded opportunities for debtors to raise questions and defenses. ${ }^{20}$

To help'debtors learn about and assert their expanding repertoire of legal rights, creditors have been required to systematically notify consumers and borrowers of their rights in many situations. To prevent needy debtors from "signing away" statutory protections in return for further extensions of credit, legislation has expressly forbidden certain kinds of waivers. To counteract litigation expenses, laws such as the federal Truth in Lending Act (1968) have empowered successful debtors (and their lawyers) to recover attorneys' fees and punitive damages. Government has directly absorbed some of the costs of asserting debtors' rights through federally funded neighborhood-based lawyers for the poor and through state and local consumer fraud units that investigate

enabling consumer-debtors to assert breach of warranty defenses when sued by finance companies (Whitford, 1979: 1087). Similarly, courts and legislatures in a number of states established a warranty of habitability, empowering tenants of ill-maintained premises to resist landlords' suits for unpaid rent (see, generally, Starr, 1979).

19 A complex line of U.S. Supreme Court cases on the subject began with Sniadach v. Family Finance Corp. and continued with Fuentes v. Shevin, Mitchell v. W. T. Grant Co., and North Georgia Finishing Inc. v. Di-chem Inc. Self-help repossession without a prior hearing, however, is still permitted with respect to automobiles and certain other kinds of property subject to direct sale liens.

20 The 1970s also saw a major expansion of laws seeking to prevent discrimination in the lending process. The federal Equal Credit Opportunity Act (1974) forbids discrimination on the basis of sex, marital status, race, age, or receipt of public assistance (Gelb and Palley, 1982). Federal Reserve Board regulations instruct lenders to notify rejected applicants of the reason therefor and tell them what agency they might complain to. The Fair Credit Reporting Act requires lenders to inform applicants if credit is denied because of adverse information from a credit reporting agency. Regulatory agencies have forbidden lending institutions to engage in "red-lining" practices that deny mortgages to residents in poor neighborhoods. These equal access to credit laws bear on the debt collection process only if they result in higher-risk loans and more defaults. Some restrictive regulation of lenders' practices, however, may result in the reduction of credit extended to higher-risk borrowers. In Maine, for example, legislative limits on repeated extensions of loans to individual borrowers led to a sharp decline in the number of small loan offices and in small loans (Benston, 1977). 
complaints about lending and sales practices. Sometimes the notice and public assistance aspects have been combined, as in a California law that compels licensed debt collection agencies to include in each collection letter a prominent statement giving the debtor the telephone number of the state agency that enforces fair debt collection laws.

Creditors, of course, have not been wholly passive. In reaction to the increased litigation costs threatened by the elimination of pre-judgment remedies, lenders and merchants more often insist on credit agreements obligating debtors to pay the bank or finance company's attorneys' fees in the event of a default. Creditors, too, lobby the legislatures, seeking to carve out exceptions in recently enacted consumer protection statutes, adjust the categories of loans to which different maximum interest rates apply, and so on. To escape ceilings on interest, they invent new kinds of finance or service charges or base their calculations on a truncated 360-day year. Consumer advocates then return to lobby for amendments outlawing or restricting the creditor's adaptations. ${ }^{21}$ In recent decades, therefore, debtor and creditor law has constantly been in flux.

Reading this catalogue of legal changes, one might have expected a major explosion of contested debt cases in the courts during the last twenty years rather than the observed decline. A sample of state supreme court debt cases from 1965 and 1970, however, reflects an almost total absence of issues arising out of modern consumer protection law; the cases were hardly different in nature from those of 1900 . From the standpoint of the hypothesis that political activism in a policy area will engender increased litigation, these results seem anomalous.

The anomaly can be partially resolved by recognizing that a major effect of new debtors' rights is to increase creditors' litigation costs, reducing the latter's incentive to sue (or to resist debtors' claims). If the law exempts larger amounts of debtors' property from execution, prevents creditors from collecting deficiency judgments, and so on, creditors are encouraged to resort to informal collection efforts rather than

21 For example, a state legislature imposes a $12 \%$ interest ceiling on unsecured personal loans of $\$ 1000$ or more, and $18 \%$ for small loans. Some finance companies respond to married couples requesting a $\$ 1000$ loan by issuing two separate $\$ 500$ loans to the husband and to the wife, each at $18 \%$. The legislature responds by forbidding finance companies to issue separate loans to a husband and wife for that purpose. 
to use the courts (Whitford, 1979). ${ }^{22}$ Greater debtor access to attorneys reduces creditors' inclinations to bring collection suits against feisty debtors or to pursue contested cases to trial or to higher courts. ${ }^{23}$

The prominence of legislative and regulatory action in the elaboration of debtors' rights also suggests that the forum for political action has shifted, so that seekers of legal change no longer go to state supreme courts but to state and federal legislatures and regulatory rule-makers. Consumers with legal defenses, perhaps, now go to regulatory agencies for assistance, leaving only debtors with no defenses in the judicial process. Perhaps, with the rise of federal law, the federal courts are now where the action is.

There is some weight to these arguments, but not enough to fully explain the decline in litigation. Although some legal changes may deter litigation, and major changes may now be sought more readily in legislatures, a rapidly changing body of law inevitably gives rise to enormous numbers of ambiguities of interpretation and application, any one of which provides thousands of creditors and debtors opportunities to seek some advantage in the courts. Losers in the legislature or regulatory agency still have every incentive to press cases in the courts, either on constitutional grounds or to secure a favorable statutory interpretation. Conflicts between the letter of the law and the equities of the situation, of the kind that filled state supreme court dockets decades ago, probably have become more rather than less numerous as the body of laws and regulations has grown (Bardach and Kagan, 1982). Finally, recent increases in contract-related cases in the federal courts are insufficient to make up for the decline of contested cases in state supreme and superior courts. ${ }^{24}$

22 Thus, in Texas and Florida, the president of the California debt collection agencies' association told me, the abolition of wage garnishment results in sharply lower court use by collection agencies because a court judgment is "almost worthless" (see Anderson, 1975).

23 Professor Whitford reports, "I have heard many legal services lawyers allege that they can win nearly any consumer credit case, regardless of the merits, simply by initiating extensive discovery or by exploiting some other litigation device" (Whitford, 1979: 1094). A lawyer for a large bank told me he sometimes will pay "nuisance fees" to debtors' attorneys to settle claims he regards as spurious, in order to avoid litigation expenses.

24 In all U.S. Courts of Appeals, contract actions filed under federal question jurisdiction show only a negligible increase, from a total of 60 in 1965 to 109 in 1970 and 137 in 1977 . Contract cases filed on diversity grounds grew from 321 U.S. Courts of Appeals cases in 1965 to 996 in 1977. Half of these might be debt collection cases, although any estimate is quite speculative, because the data assembled by the Administrative Office of the Courts do not indicate type of contract case, and I suspect that non-debt-collection contract cases represent a larger proportion of "all contract" cases in federal diversity cases 
It might be argued that the expansion of debtor rights has not produced an explosion of hotly contested state court cases and appeals because debtors, by and large, remain ignorant of their rights or unwilling to assert them because of the direct and indirect costs of litigating. One study found that only 5 percent of a sample of consumer debtors who were sued in urban courts filed an answer, even though one-third believed that they had at least a partial defense (Caplovitz, 1974). Stewart Macaulay discovered that many Wisconsin attorneys knew little about recent federal laws affecting consumer rights, and that they were unwilling to litigate consumer claims that did not involve large dollar amounts (Macaulay, 1979). Counsel for a large bank whom I interviewed also spoke of the ignorance of many debtors' lawyers about possible legal claims. Judges in small claims courts in fourteen states, interviewed by Ruhnka and his colleagues, said that federal and state consumer protection requirements are rarely raised, either affirmatively or as a defense (Ruhnka et al., 1978). Finally, the president of California's association of collection agencies told me that members now encounter legal defenses in prelitigation discussions in perhaps 5 percent of cases. This is an increase from the "almost never" of ten or fifteen years ago, but it is still a small proportion.

This research, however, relates entirely to the small claims debt collection process, which has remained a low-level, legally routinized process. Ignorance and litigation costs do not explain why contested cases involving larger debts, for which litigation costs are comparatively smaller, have not been stimulated by changes in the law. The Wisconsin Civil Litigation Project found little passivity among a sample of households with grievances growing out of debt or consumer problems amounting to $\$ 1000$ or more. Households transformed such grievances into claims over 90 percent of the time. They persisted, usually successfully and not infrequently with a lawyer's aid, when they met resistance (which was most of the

than in state courts. In any case, the increase of, say, 300 or $400 \mathrm{debt}$ cases in federal courts is not equivalent to the decline in state supreme court cases from their pre-1930 levels.

At the U.S. District Court level, cases involving "negotiable instruments" (a category used in the administrative reports) declined from 4390 annually in 1965 to 2355 in 1977. The Truth-in-Lending law, which reputedly has given rise to many court cases, was the basis for 1682 U.S. District Court cases in 1974, 2237 in 1975, and 2183 in 1977. "Other contract" cases did increase, however, from 4490 in 1965 to 13,493 in 1977. Again, assuming that half of these were debt cases, the 3500 increase in all U.S. District Court cases represents but a tiny fraction of debt actions in state courts. In California alone, there were 88,200 Superior Court contract cases in 1975. Debt litigation, even if increasing in the federal courts, remains concentrated in state courts. 
time) (Miller and Sarat, 1980-81). Other studies of households with consumer grievances show a high propensity to protest and a high rate of success (see Miller and Sarat, 1980-81: 52931 ), which tends to counteract the image of the acquiescent debtor. A debt collection agency president, whom I asked to explain the significant decline in the average recovery rate achieved by collection companies-from about 33 cents on the dollar in 1965 to 24.7 cents in 1975-1980 (American Collectors Ass'n, 1980)-emphasized changing attitudes: the bill collector's traditional asset-that debtors are afraid of him, plagued by guilt feelings, and embarrassed-has been eroded by an increasing proportion of debtors who seem unconcerned about their reputations and are willing to stall or be defiant.

In any case, there is no obvious reason to believe that debtors are in general more acquiescent when they have colorable claims than they were in earlier decades. Therefore, the apparent decline of legal disputes in recent decades might have occurred, as the legal rationalization concept suggests, because creditors quickly adapted to legal changes, so that many cases remain in which debtors quite accurately perceive that they have no legitimate defense. The trend toward legal rationalization may be complemented by a decline (for good economic reasons) in "toughness" on the part of creditors that is manifested in a tendency for lenders to acquiesce in new legal restrictions and to "give in" in the few cases in which debtors make some show of legal resistance. Political conflict over creditors' rights may not lead to more legal conflict if, despite legal change, creditors have become less disposed to enforce the law strictly against debtors and more attentive to other ways of cutting or recouping their losses. To these possibilities we now turn. ${ }^{25}$

25 There is also the possibility that the debtors' rights legislation of the 1960 s and 1970 s did not lead to much legal conflict because it did not stem from a true political conflict. The consumer movement of that period might be viewed as a political organization of urban consumer-debtors, analogous to the agrarian producer-debtors who took action against their creditors in earlier eras. In reality, however, most consumer legislation met with remarkably little opposition from Congressmen who seemed happy to support new liberal programs that did not cost the government or taxpayers much money (see Bardach and Kagan, 1982: Ch.1). Unlike earlier reform movements, this one was encouraged rather than resisted by the courts. In contrast to the Populist and labor movements, the consumer movement did not call for any significant redistribution of power or control of the means of production. There was no serious demand for popular control of lending and credit institutions, or for the government to take over the debt collection process (as in Switzerland), or for radical change in the substance of debtor-creditor law (such as the abolition of all coercive execution remedies or of all pre-judgment repossession of secured property, or the creation of an "excusable default" rule to ensure that the debtor who in good faith cannot pay a few installments can no longer be held liable for accelerated payment of the entire debt) (see Whitford, 1979). One 


\section{SYSTEMIC STABILIZATION}

The concept of legal stabilization discussed earlier refers to laws, contractual provisions, and procedures governing discrete transactions and disputes. The underlying hypothesis is that the gradual development of a more comprehensive body of laws and contractual arrangements, routinely applied by legal and bureaucratic specialists, has come to provide out-of-court legal "solutions" to an increasing proportion of individual conflicts. An even more significant litigation-suppressing factor, however, may be systemic stabilization. By this, I mean the development of large-scale economic and social institutions that ameliorate the conditions that cause individual conflicts or that provide collective, administrative remedies (as contrasted to case-by-case legal remedies).

The idea of systemic stabilization does not presume an ineluctable social evolution toward rational collective problemsolving or toward stable and effective economic markets. But it does presume that in modern democratic and capitalist societies political demands will often reflect some version of those ideals. The political agenda of the debtor class over the last two centuries, for example, has been dominated less by the quest for specific legal rights, such as the better disclosure of finance charges in individual credit transactions, than by more fundamental (and controversial) demands for systemic solutions to common problems. Judging from Shays' Rebellion, the Populist movement, and New Deal era agitation, debtors' highest priorities have been (1) an "easy money" policy, (2) reliable and flexible sources of credit, and (3) some form of systemic relief-a moratorium, supplementary income, etc.-to help "honest debtors" over those "hard times" that make debt payments unmanageable because of events such as falling crop prices, economic depressions, illness, and lost jobs that are beyond the debtor's control.

Modern democratic polities have often responded to demands for "easy money" and income support programs, and they have encouraged the stabilization of private markets through regulation and insurance schemes. To political and economic elites, the development of demand-enhancing, cushioning, and stabilizing measures has been perceived, at

might argue, therefore, with only some exaggeration, that lending institutions and merchants did not fight back in court because they were not deeply threatened. They became part of the political consensus that the consumer movement called for because they could live with its limited demands for fair play in individual transactions. 
least up to a point, as more efficient as well as more politically popular than relying on a system based entirely on free market transactions, tempered and policed only by individually initiated lawsuits that punish individual delicts. Among the primary institutional vehicles for the favored type of systemic problem-solving are (1) governmental regulation and subsidization, designed to stabilize potentially problem-causing economic processes, and (2) loss spreading or "absorption" via large, diversified economic institutions and insurance systems.

The rise of effective regulatory and insurance mechanisms to deal with certain problems, or the domination of certain markets by large, diversified business units, can reduce the incidence or growth of private-law litigation by eliminating incentives to sue and by reducing the incidence of conflict. For example, the growth of litigation arising from motor vehicle accidents might be dampened both by the creation of comprehensive mandatory "no fault" self-insurance schemes and by governmentally enforced safety standards for highway design, trucking company practices, and the design of motor vehicles. The development of safer vehicles is also facilitated by the growth of large manufacturers with modern research and quality control capacities.

Similarly, the growth of large, diversified financial institutions and of private and governmental insurance against financial hardship may provide the most powerful explanation for the relative diminution, in recent decades, of intense debtor-creditor conflict in the courts. In relation to the factors discussed earlier, such systemic changes create a rich array of possibilities for recouping losses, and thereby: (1) reduce the incentives that creditors have to treat delinquencies as defaults that warrant immediate court action, (2) make litigation and appeal for both debtors and creditors a relatively costly way of recouping or avoiding losses, and (3) encourage one aspect of legal rationalization, i.e., more rapid compliance by lending institutions with debtor protection legislation. To understand the impact of these systemic changes, however, we must first look back at the credit market as it was a century ago.

\section{Sources of Instability}

Reading the debt collection cases of late nineteenthcentury state supreme courts creates an overwhelming impression of a far less stable credit system than that which exists today. Many cases involved claims against failed banks or arose in the train of bank failures. In the 1890s, there were 
an average of more than 100 bank failures per year, out of a nationwide total of about 4000 state-chartered banks. (There were also some 3500 federally chartered banks, which were more tightly regulated.) (Historical Statistics, 1975; Robertson and Walton, 1979: 380-81.) This suggests that there was a significant chance that the bank one trusted with one's money or borrowed from would shut down with little warning. It was even more likely that one's bank would close its doors for a time or suddenly call in or refuse to extend loans, because of the currency shortages that occurred almost every harvest season and periodically resulted in terrifying financial panics (Robertson and Walton, 1979).

Late nineteenth-century state supreme court cases also suggest that lending then was far riskier and the security for loans far flimsier than is the case in today's credit markets. Competition for new sources of potential profit in a rapidly changing economy, as Robert Silverman writes of late nineteenth-century Boston, "drove retailers, wholesalers, bankers, brokers, landlords or builders to extend credit unwisely" (Silverman, 1981: 145). Reliable credit information about would-be borrowers was notably lacking. Many state supreme court cases grew out of situations in which con men (or desperate businessmen) mortgaged the same property to two creditors, or fraudulently acquired goods on credit and then skipped town. ${ }^{26}$

Most creditors whose cases reached state supreme courts in the late nineteenth and early twentieth centuries were not large companies or banks, but were individuals-such as a small businessman who had extended credit on a sale of merchandise or a farmer who had bought extra land at an execution sale only to encounter the competing claim of an unknown lienholder. Often creditors' only security was that debtors had supplied individual sureties-friends or relativesto back up their promises to pay. Viewed through the lens of SSC cases, credit transactions gave rise to an inordinate amount of litigation over how to distribute obligations among

26 The Michigan Supreme Court, in a typical case of this type, had to consider whether a loss should fall on Hewitt, who had sold a half-interest in his mill to Messrs. Stewart and Oliver for a supply of lumber but had failed to ascertain that their lumber was encumbered by a chattel mortgage held by the owner of the land from which the timber was taken. The trial court had compelled Hewitt to turn over the lumber, by now fully processed, to the landowner. Stewart and Oliver, it seems, had disappeared without paying the landowner and without paying the loggers whom they had hired to cut the timber, leaving the latter with "loggers' liens" on poor Hewitt's lumber, an interest that the loggers contended, without success, should give them priority over the chattel mortgage holder. Cass v. Gunnison, Administrator For Hewitt. 
sureties or between sureties and the debtor or creditors. ${ }^{27}$

If problems of insufficient information, inadequate security arrangements, and unstable financial institutions and markets were at the root of creditor-debtor (and inter-creditor) conflicts in the late nineteenth century, the most profound differences between the credit world of that era and the post-World War II period lie neither in changes in the law of creditors' rights nor in the changed incidence of delinquency or default. The crucial changes involve the various ways that today's creditors can insure against debtor delinquency and the greater access debtors now have to sources of emergency funds that can ensure, without recourse to litigation, that payment eventually will be made or that losses will be cushioned and spread. Some of these systemic developments are worth spelling out.

\section{The Stabilization of Banking}

In the $1890 \mathrm{~s}$, there were over 1300 bank failures in the United States; in the 1920s there were 2900. In 1930-1933, there were 9100 failures, a crisis exacerbated by the Federal Reserve Board's failure to distribute reserves and expand the money supply during 1930. In marked contrast, during the 1947-1960 period there were only 66 bank failures in the nation, and only 62 from 1961 through 1970. The few failures that occurred each year in recent decades were concentrated in banks with less than $\$ 100$ million in deposits, and nearly three-fourths were among banks with less than $\$ 1$ million in deposits. When large banks have failed, the Federal Deposit Insurance Corporation, established in 1933, has usually arranged for a merger; in cases

27 Here is one colorful example: Ray $v$. Profett, an 1885 Tennessee Supreme Court case, arose some time after Solomon Ray, a North Carolina sheriff, took money he had collected and absconded across the mountains into Tennessee, where he bought himself some land (for $\$ 4500$ ). Some time later, Hensely, the son-in-law of David Profett, one of the sheriff's sureties, followed Solomon Ray's trail to Tennessee. By then, the sheriff had died, but the land endured, and Profett (through Hensely) sued the sheriff's heirs in a Tennessee court, claiming he had been forced to make good on the sheriff's embezzlement back in North Carolina. Profett won a judgment awarding him three-fourths of the land. But then over the mountains came A. E. Jackson, one of the creditors whose money (\$589.94) the sheriff had taken. Jackson got a court order attaching the land and sued Profett. The case "was litigated for a considerable time," the Tennessee Supreme Court noted, but Jackson won a decree subjecting the land to sale for satisfaction of his original judgment. Before it could be sold, however, over the mountains came A. E. Ray, who sued Profett and Jackson, claiming that he too was one of the sheriff's sureties; that he had paid more of the sheriff's obligations than Profett (although neither, it later turned out, had paid much); that Profett's claim had been fraudulent; and that he (A. E. Ray) was entitied to at. least some of the land. The Tennessee Supreme Court toiled away at unraveling this tangled skein and finally held that the land should be sold, the proceeds used first to satisfy Jackson's claim, and the rest divided between Profett and $A$. E. Ray in proportion to the amount of the sheriff's debts each could prove he actually paid. 
of liquidation, depositors have been paid off immediately (B. Friedman, 1980).

This stability has been encouraged by a number of factors, including: (1) the establishment and comprehensive coverage of federal deposit insurance, which has helped forestall runs on banks, the sudden calling in of loans, and domino-type financial panics; (2) intensified federal regulation of bank reserves and lending practices, along with regulations that (until recently) limited inter-bank competition and prevented banks from engaging in risky nonbanking enterprises; (3) a Federal Reserve Board that has effectively made reserves available to member banks during general "credit crunches" or when particular institutions were suffering from illiquidity; and (4) a great reduction in the number and an increase in the average size of banks, with corresponding increases in the diversification of loan portfolios and sources of income and in the rationalization of banking practices (B. Friedman, 1980: 59)..$^{28}$

\section{Insurance for Individual Debtors}

The consumer movement of the late 1960s and 1970s focused on providing new legal rights for individual buyers or debtors faced with unjust treatment or deception. But these victories have far less significance for debtor-creditor relations than the establishment of income security and welfare state protections during the New Deal and during the "Great Society" programs of the mid-1960s. A very large proportion of debtor delinquencies stems from serious illnesses or injuries, layoffs from work, and other sudden decreases in income or increases in expenses. In earlier eras, such events destroyed a debtor's capacity to keep up payments on loans. During the post-World War II period, however, unemployment insurance, disability insurance, more adequate workers' compensation payments, employer-provided health insurance, Medicare, Social Security, and private pension plans have all become widely available. For debtors, these programs guarantee some continuation of income in hard times and the possibility of maintaining some level of payments to creditors. For creditors,

28 Milton Friedman has asserted that two additional factors have been important: (1) the significant proportion of bank assets held in the form of government securities in the 1945-1970 period, which buffered banks against sudden shifts in the private credit market; (2) the loosening of links between gold stocks and prices, on the one hand, and the domestic money supply on the other, which has buffered domestic banks somewhat from international events and money flows stemming from changes in the price of gold (M. Friedman, 1980: 79). 
these income-support measures are a reason to prefer reduced payments or refinancing, backed by the debtor's continuing income stream, to a one-time attempt to attach the debtor's assets.

In addition, virtually every homeowner, small business, and motor vehicle owner now carries liability insurance, which has transformed the collection of liability judgments, often a source of further dispute and litigation in times past, into the routine drafting and mailing of a check by the corporate treasurer of the judgment-debtor's insurance company.

Perhaps the most significant form of debtor "insurance" in the 1945-1975 period has been a relatively stable economy and an improving set of job opportunities. This is in part attributable to macro-economic policies-Keynesian fiscal policy and more enlightened monetary policy-that can be viewed as aspects of "systemic stabilization," and in part attributable to the social insurance schemes mentioned above that limit the negative ripple effects of business failures and plant closings. In the 1940-1975 period, economic downturns were both shorter and shallower, on the average, than those in pre-World War II decades (B. Friedman, 1980: 12). The index of real average weekly earnings of production workers in manufacturing, using 1967 as 100, went from 66 in 1946 to 123 in 1977 (Robertson and Walton, 1979: 482-83). Disposable income per capita, controlling for inflation, increased from $\$ 2200$ to $\$ 4500$ over that same period (Blinder, 1980: 422). As we have seen, rising income and job security have not prevented an increase in loan delinquencies. But delinquent debtors are likely to have better prospects for regaining solvency, and more relatives with savings to bail them out, than did their counterparts in earlier decades. This may make creditors less inclined to sue defaulters immediately.

\section{Insurance for Creditors}

For creditors, a universe of debtors with more stable income has meant a radical improvement in security. More and more, a creditor's real security lies not in pledges of individual sureties and cosigners but in the debtor's job and job skills, which are more likely than in previous decades to generate a steady, and increasing, stream of income which, if default ensues, can be tapped via the garnishment process. Lending to a nation of civil servants, salaried managers, and unionized blue collar workers who work for substantial corporations is less risky than lending to a nation of farmers (before crop 
support payments), small proprietors, and workers in small firms. ${ }^{29}$ 'This enhanced security has been reflected in creditors' willingness to require smaller downpayments for consumer loans, and to extend average repayment periods from less than twelve months to more than two and a half years (Moore and Klein, 1967: 146). The smaller monthly payments, in turn, mean that delinquencies can more easily be recouped, presumably reducing the incentive for creditors to rush to court.

Another important source of insurance for lending institutions are the loan guarantees provided by government units. Since the end of World War II, for example, the Federal Housing Authority and the Veterans' Administration have guaranteed millions of home mortgages. Although payments are not available to mortgagees until they foreclose and attempt to collect from their mortgagors, these guarantees should reduce the incentives for contested litigation and appeals. Why fight if the government will pick up the tab? The same would seem to be true of federal guarantees to banks that extend student loans for higher education.

Creditors have also incorporated insurance programs into lending agreements. For example, some lenders now offer purchasers of homes and consumer durables "credit life insurance," which guarantees payment of the unpaid balance of the loan to the creditor in the event of the debtor's demise, and "credit disability insurance" has also become common. Home mortgage lenders are also protected by fire insurance, which the borrower is obliged to provide and pay for in monthly installments. Thus, many adverse events, instead of creating litigation-provoking zero-sum conflicts between debtors (or their estates) and their various creditors as to who will bear an entire loss, now result in charges to insurance companies or government welfare funds, which are in turn spread over millions of policy-holders or taxpayers.

\section{Insurance for Business . Debtors}

Institutional arrangements designed to help precarious businesses maintain their debt payments are not as comprehensive as protections for individuals, but they are surely more significant than in the decades before the New

29 The greater security provided by steady wage and salary incomes, as compared to farm income, is indicated by studies showing that the shortest maturities and largest down payments for small loans are associated with loans to farm operators and farm wage earners, while salaried workers and wage earners secure the easiest repayment terms. Small proprietors and professional borrowers fall somewhere in between (Moore and Klein, 1967: 52). 
Deal. Most striking is the rich array of federal incomemaintenance programs for farmers, including below-marketrate loans, acreage restriction payments, crop insurance, and price guarantees through crop support payments or governmentally approved marketing agreements (for a summary, see Robertson and Walton, 1979: Ch. 25). These stabilization measures, together with the drastic decline in the number of smaller, economically less stable farms since the 1930s, have undoubtedly produced a huge reduction in the annual number of farm failures, a major source of debt repayment problems and litigation in the late nineteenth and early twentieth centuries.

Other specific kinds of business borrowers and their creditors benefit from loan guarantees offered by the federal Overseas Investors' Protection Corporation and the Security Investors' Protection Corporation, both loosely modeled on the FDIC. The Small Business Administration has guaranteed billions of dollars of low-interest private loans to small companies, a riskier-than-average set of debtors ${ }^{30}$ (Robinson, 1980). When businesses are threatened with income losses or heavy expenses as a result of floods and earthquakes, the government refinances existing debts by offering below-marketrate interest loans to firms in the "disaster area."31 Special federal loan guarantees have been given to creditors who extended existing loans to huge entities, such as Chrysler Corporation and New York City, that were on the verge of default and threatened to pull creditors down with them.

The result of these and similar programs is that, by some estimates, the federal government issues, guarantees, or stands as lender of last resort with respect to "well over half of the total financial assets of the public" (M. Friedman, 1980: 80). In addition, state governments stand as guarantors for many of the debt obligations of municipalities, housing authorities, irrigation districts, and the like, while federal and state grants enable financially hard-pressed public agencies to acquire money for special projects without having to commit themselves to repayment. These guarantees and direct grants are significant because repayment failures by local public

30 The SBA's "loss rate" on small business loans is estimated at $6 \%$, compared to a loss rate of less than $1 \%$ on ordinary commercial bank loans (Robinson, 1980: 294).

31 In addition, many businesses now carry commercially available disaster insurance, business interruption insurance, and key man insurance, which facilitate their ability to keep up some level of debt payments over a period of hard times. 
bodies were an important source of litigation in the 1930s and in earlier depression periods.

Another indicator of systemic stabilization is the expectation that governments will take action to provide relief for debtors during hard times. The U.S. Constitution's "contract clause," promulgated in reaction to the "stay laws" and other state debtor relief laws of the 1780s' (see McDonald, 1982), was used by the courts throughout the nineteenth century to block such measures (Wright, 1938; L. Friedman, 1973). However, in 1934, in Home Building and Loan $v$. Blaisdell, the Supreme Court virtually removed the contract clause from the Constitution, upholding a Depression-inspired Minnesota law declaring a moratorium on mortgage foreclosure. Since then, there seems to be a widespread political expectation that governments will protect debtors and bail out their creditors in times of distress. During World War II, the federal Soldiers' and Sailors' Civil Relief Act granted servicemen a moratorium on foreclosures and debt actions, which may help explain the sharp drop in litigation in the 1940s. During the recent recession, Congress voted to appropriate several hundred millions of dollars to the Farmers Home Administration in order to provide farm mortgage relief, and $\$ 760$ million to be used to maintain mortgage payments for unemployed homeowners (FHA and VA guaranteed loans had already obligated the lending institution to postpone foreclosure when the homeowner is unemployed) (Wall Street Journal, May 4 and 14, 1983).

\section{Diversification in Credit Markets}

Since 1950 , a smaller proportion of loans has flowed directly between individuals, or between businesses and individuals. By 1970, loans to households and businesses were extended mostly by "financial intermediaries" to which households and businesses commit their funds-commercial banks, savings and loan associations, insurance companies, consumer finance companies, pension trusts, and governmental credit-granting agencies (B. Friedman, 1980: 36-42). Economists point out that financial intermediation increases the efficiency of the credit system because it makes for more professional and informed credit decisions and the diversification of risks (Meckling, 1977: 17). I discovered no indicators of how the growth of financial intermediation affects propensities to litigate over delinquent debts, but it is reasonable to suppose that the big bank or insurance company faced with mortgagors behind on payments 
can afford to be more lenient than a small landlord owed three months' rent by a tenant. Large lending institutions set aside reserves for bad debts and are prepared to live with delinquencies in amounts that don't threaten to exceed the planned reserves. Indeed, they write off bad debts before sending such accounts to collection agencies, which means that any that turn out to be recoverable are just "gravy." Unrecovered losses are treated as additional costs that can be reflected, at least in part, in next year's finance charges and spread over the pool of new borrowers. Losses can also be deducted from federal and state corporate tax obligations, which means not only that they are shared with millions of taxpayers but also that the "real" loss is smaller and more likely to exceed litigation costs. In economic theory, of course, a large lender operates under competitive pressure to limit losses and, like the small landlord or businessman, would litigate if necessary to collect any debt whenever the prospects for recovery exceed litigation costs. But because they have institutionalized mechanisms for routinely accounting for losses and attempting to recoup them, large lenders are, I suspect, less inclined to spend additional money to sue the debtor who fails to pay a judgment or to appeal the case that is lost in the lower courts. The government in its growing role as creditor seems even more inclined to absorb and spread losses rather than litigate to collect delinquent debts. ${ }^{32}$

Diversification in financial markets goes beyond lossspreading within the loan portfolios of large lenders. Borrowers have seen a remarkable diversification of sources of credit. The licensing of small loan companies and the regulation of maximum interest rates have helped transform a turn-of-the-century industry of small and unscrupulous "loan sharks" into a more stable, lawful industry of consumer finance companies, many of which operate on a scale sufficient to spread their risks over thousands of borrowers and attract stable financing from banks and other lenders (Michelman, 1966). The growth of nonbank lenders, such as pension funds, government agencies, and investment trusts, has also helped provide a more competitive and richer credit environment, thus multiplying opportunities for troubled debtors to forestall

32 The President's Private Sector Commission on Cost Control recently announced that at the end of $1982, \$ 301$ billion was owed the federal government, of which about one-third was due immediately or within one year. Over $40 \%$, or $\$ 38$ billion, of these "current receivables" were classified as delinquent. Over $\$ 2$ billion in student loans was in default, $\$ 65$ million of which was owed by 41,000 current and retired federal employees (Grace, 1984). 
litigation by obtaining refinancing agreements, second mortgages on their homes, and additional credit. Under competitive pressure, banks have moved toward more flexible lending arrangements, including long-term loans to business firms and revolving credit (B. Friedman, 1980: 46).

Systemic stabilization has also been increased by the greater fluidity of credit brought about by the expansion of the proportion of loans that are "negotiable." Lenders hold transferrable "commercial paper" and publicly traded corporate bonds instead of less marketable direct loans. In the 1960 s, a secondary mortgage market made home mortgages, in effect, negotiable (B. Friedman, 1980: 56). Negotiability means greater liquidity; when lenders need funds, they can "sell" rather than call in loans. Liquidity is another form of insurance, in this instance for creditors, but one that would seem to reduce zero-sum conflicts with debtors.

\section{Bankruptcy}

I have noted that federal bankruptcy proceedings are a form of legal rationalization in that they provide an efficient forum for assembling and establishing priorities among competing creditors' claims. However, another feature of bankruptcy, the debtor's discharge from most existing debts, is empirically more important. Stanley and Girth discovered that 70 to 75 percent of bankruptcy cases in the years $1965-68$ were "no asset" cases in which creditors recovered nothing, and 10 to 15 percent were "nominal asset cases" in which creditors got little. In the remaining "asset cases," creditors asserted claims totaling $\$ 431$ million but recovered only $\$ 70$ million, or 16 cents on the dollar (Stanley and Girth, 1971: 21). The growing ratio of individual to business bankruptcy cases in the 1970s probably increased the proportion of no asset-no recovery cases. Therefore, in the vast preponderance of modern bankruptcy matters, competing creditors have little to litigate about. The prominence of the discharge function suggests that bankruptcy as it in fact operates is primarily a form of socially provided "insurance" for debtors, an escape hatch for victims of financial disaster, rather than a means of more efficient adjudication. Indeed, most of the justifications for bankruptcy suggest that it is a product of pressures for "systemic stabilization." Most legal commentators seem to view bankruptcy in wholly amoral terms as a system for inducing risk-taking and hence an engine for economic growth. The discharge of "failed" debtors in bankruptcy, according to a typical comment, "may be viewed as 
a cost of the existing credit system-a cost that is widely diffused ... borne partly by borrowers as a whole through higher interest rates, but principally by customers of business through higher prices" (Stanley and Girth, 1971: 40). While voluntary bankruptcy at one time was morally suspect, the primary "moral" concerns of the 1970 Commission on the Bankruptcy Laws seemed to be only that individual debtors should be equally well-informed about the availability of discharge; that discharge should be made cheaper, less legalistic and lawyer-dominated, and more like a routine administrative proceeding; and that debtors should be protected against creditors' attempts to secure the reaffirmation of debts discharged in bankruptcy in return for new extensions for credit. ${ }^{33}$

This "non-stigmatizing" attitude toward bankruptcy, abetted by court rulings forbidding restrictions on lawyer advertising, has been reflected in steeply increasing individual bankruptcy filings-25,040 in 1950, 191,724 in 1967 (Stanley and Girth, 1971: 25), and an estimated 450,000 in 1982, the equivalent of the population of a large city. Studies indicate that most non-business bankruptcy filings are preceded by a threat of legal action against the debtor (presumably in state court), but very few bankruptcy cases are preceded by an actual state court judgment in favor of creditors (U.S. Commission on Bankruptcy Laws, 1973: 50). This suggests that legally sophisticated debtors, those whom one might expect to raise possible legal defenses in state trial or appellate courts, are now more inclined to take the "escape hatch" route of bankruptcy. Compared to protracted litigation, the routinized "loss-spreading" bankruptcy mechanism becomes increasingly appealing.

\section{CONCLUSION}

In sum, despite the marked growth over the last thirty-five years in lending and in the volume of delinquent debts, the

33 Underlying this view of bankruptcy, it seems, is an inchoate vision of the law as encouraging what might be called the "entrepreneurial household," the consumer equivalent of the risk-taking business firm. Just as the invention of the corporate form encouraged investment by limiting liability, the ready availability of bankruptcy, along with generous exemptions (property that the debtor can retain) and limitations on garnishment, encourages consumers to take the risk of buying on credit. The injustice to creditors not repaid is equivalent to the injustice to business creditors, loyal workers, and community members when an unprofitable business is legally allowed to shut down and open a new facility in a lower-wage sunbelt community. The aggregate-benefit, systemic perspective prevails over the individualistic, commutative justice perspective. 
number of state supreme court debt cases has declined sharply, and there has been an apparent decrease in contested debt cases in trial courts of general jurisdiction. The decline in contested debt cases cannot be explained by a simple causal model that links the incidence of court cases in a policy area to the rate of problem-causing events. An intuitively obvious intervening factor is the variable cost of litigation, defined to include both direct costs (such as attorneys' fees) and opportunity costs (such as time lost from productive work, delays in attempting to collect judgments, etc.). Direct evidence is lacking, but it is reasonable to suppose that in the post-World War II era a smaller proportion of delinquencies led to collection cases and a smaller proportion of cases were contested because litigation costs rose, at least in relation to the cost of alternative courses of action-such as arbitration, bankruptcy, additional extensions of time, refinancing, "writing off' bad debts, or confessing liability.

Although direct evidence is not available, it appears that three factors have contributed to the increased attractiveness of nonlitigation alternatives. ${ }^{34}$ One such factor has been legal rationalization, especially the development by lenders of legally "airtight" contractual provisions and security arrangements specifically designed to forestall litigation, and their increasing use of lawyers and other specialists in the routine settlement of debt cases. These measures presumably reduce the proportion of debt disputes involving viable defenses and make settlement correspondingly more attractive. The second factor is an increase in the political activity of debtors and their allies. Political action-primarily on behalf of homeowners, farmers, and small businesses in the 1930s and on behalf of consumers in the 1960s-has shifted the locus of demands for reformed debtor-creditor laws away from courts and toward legislatures and regulatory agencies, stimulated the enactment of a multitude of new defenses for consumerdebtors, and enhanced opportunities to learn about and assert

34 In emphasizing the economic costs and structural incentives that discourage litigation, I intentionally have not considered political or cultural attitudes toward conflict or litigiousness, which a number of scholars have attempted to link to cross-jurisdictional variations in litigation rates (see, e.g., Grossman et al., 1982; Jacob, 1969). To explain a decline in litigation within the same (national) population over time, I believe changes in law, in the availability of "cheaper" alternatives to litigation, and in other factors affecting the cost-benefit ratio associated with litigation are more fundamentally important. For the same reason, I omit consideration of the attitudes and conventions of the local bar and bench, which clearly do produce crossjurisdictional variations in the levels of court use and legal conflict, as shown by studies of criminal courts (Eisenstein and Jacob, 1977) and bankruptcy courts (Shuchman, 1977). 
these rights. Judging from the fact that the number of contested debt cases has not increased in recent decades, the primary effect of the expansion of debtors' rights and remedies has been to increase the cost of litigation for creditors in cases in which debtors show some inclination toward legal resistance.

The third factor forestalling debt collection litigation, and undoubtedly the most significant one, has been a trend toward systemic stabilization-the development of methods of lossspreading, diversification, insurance, and economic stabilization that prevent financial panics, blunt the edges of individual disputes, and encourage consensual refinancing or absorption of losses rather than protracted litigation. In the 1880 s (and even in the 1920s, in the South) the farmer who could not pay off his crop mortgage was threatened simultaneously with the loss of his home and livelihood. The shopkeeper or small manufacturer who could not pay his debts faced similar ruin, as did many a creditor whose debtor could not pay. For them, it made sense to fight for survival in the courts if any plausible legal argument could be made. But this debtor class of small farmers, shopkeepers, and artisans has been replaced by a debtor class composed of incorporated businesses, whose owners and managers usually can find other jobs if their firms face insolvency, and of unionized workers and salaried government employees whose debts are backed by relatively reliable sources of income and various forms of social insurance. For both groups of debtors, bankruptcy has become an increasingly less stigmatizing and more frequently used way of escaping debt and obtaining a fresh start. In parallel fashion, from a creditor class of small banks, merchants, and individual speculators, we have evolved a creditor class of large, diversified, insured lending institutions, department stores, and hospitals. Unpaid loans become tax write-offs and increased costs to be reflected in next month's prices or interest rates. The government and insurance companies back up mortgages. New lenders stand ready to refinance the failing and to relend money to the formerly bankrupt.

As a result of such systemic changes, in comparison to times past there are now fewer loans, proportionately and perhaps absolutely, that debtors and creditors find worth "taking to the supreme court," or even worth contesting in the trial court. If debtors and creditors are better able as a class to absorb losses, or to pass them off on others, the opportunity costs of struggling toward legal victory in court have gone up 
and incentives to litigate have gone down. More merchants simply give in to the dissatisfied customer (Ross and Littlefield, 1978). Banks more often help arrange refinancing for a financially troubled corporation or entrepreneur rather than losing all by pushing the debtor into bankruptcy.

The rate of legal rationalization and the impact of political conflict have also been affected by systemic stabilization. Diversified and regulated credit markets have encouraged the growing dominance of large, bureaucratic credit institutions that are quick to learn about new legal rulings and quick to translate them into routine practices. Banks, finance companies, and department store chains treat new debtors' rights as another set of contingencies to be insured against, absorbed, and passed on as higher costs. Corporate lawyers devise new forms incorporating the prescribed warnings. Deprived of "holder in due course" defenses, banks and finance companies insert provisions for reimbursement in their contracts with merchants, or threaten not to deal with merchants whose customers often express dissatisfaction. An attorney for a major California bank told me that because the appellate courts are perceived as pro-consumer, adverse trial court decisions will not be appealed and novel debtors' rights claims will be settled. Complying with regulatory restrictions, a debt collection agency official told me, drives up collection costs, which renders it less feasible to pursue the substantial number of "skips," debtors who have left their home and the job they held at the time of the loan and hence are expensive to locate. The costs of compliance with regulations, and any additional losses in repayment that result, end up as costs of doing business, spread over the 95 percent of borrowers who repay their loans without incident. ${ }^{35}$

Of course, as the last phrase suggests, there are costs, both economic and moral, associated with a system based on lossabsorption and spreading, and hence there may be both political and economic limits on the toleration of unpunished delinquency. But even if systemic stabilization would in the long run counterpose some economic efficiency restraints against the political quest for security and harmony (and this is

35 This is not a uniform response, of course. On the margins of the lending industry, far away from the banks, large savings and loans, and department stores, are very small finance companies, collection agencies, landlords, and local merchants who deal with the poor and are undoubtedly less likely to comply automatically and bureaucratically with regulatory efforts. Hence, further reforms in consumer credit law may well be desirable (Whitford, 1979), even though the trend is toward larger, more reliable credit institutions. 
far from certain), it may not do so in the short run. The factors that drive systemic stabilization or disrupt it are undoubtedly both complex and poorly understood. Yet a full understanding of what has happened and is likely to occur with respect to the legal collection of debts requires further attention to the actions that constitute systemic stabilization ${ }^{36}$ and attention to the political and cultural forces that create and oppose it.

For example, the institutional stabilization of creditors and collective loss-spreading is not a monolithic, unidirectional trend. The most significant countertrend, perhaps, is the destabilization of households as reliable economic units through family disruption, as reflected in increased rates of divorce, unmarried parenthood, and female-headed homes. Governmental welfare programs represent a partial "collective," social-insurance approach to the resultant growth of financially hard-pressed households. But the splitting and diminution of household income stemming from family disintegration also increase the probability of loan defaults, and have given rise to what has probably been the most rapidly increasing form of debt-collection litigation in the last decadesuits both by abandoned mothers and by governmental units to recover unpaid child-support obligations ${ }^{37}$ (Chambers, 1979; Schorr, 1983).

Moreover, it is not clear that systemic stabilization, if it is viewed as a process that substitutes collective insurance and loss-spreading for particularistic legal conflict, applies as fully to other substantive areas of litigation or has the same impact. Whether the inefficiencies of personal injury litigation will be displaced by generous "no fault" systems of private or governmental insurance is, for example, far from clear. The private plaintiffs' bar and the cupidity engendered by occasional massive jury awards are not the only obstacles. Another is the strength of the cultural impulse to condemn,

36 The concept of systemic stabilization as used in this exploratory article is admittedly not carefully defined, so that one cannot easily decide whether a particular government policy or institutional development is within or outside of its boundaries. Until the definitional task is undertaken, it will be difficult to apply the notion of systemic stabilization to other policy areas, to measure its degree and impact, or to test hypotheses concerning its importance.

37 In addition, the huge debts accumulated by a number of Third World nations following the worldwide increase in oil prices in the 1970s now threaten the stability of American banks. Another destabilizing element is the increasing vulnerability of "smokestack industries" to international competition. Still another is the government's inability to withstand political pressures for deficit spending, which periodically threatens large increases in interest rates and thereby increases risks of default. The overall trend toward systemic stabilization, therefore, is only a relative one. I do not mean to imply that credit and repayment problems have been "solved." 
punish, and deter individuals and organizations whose carelessness causes human injury, illness, and death. Perhaps the strength of the movement toward insurance and lossspreading in the debt-collection field has gone as far as it has only because we are culturally willing to see the debtor who cannot pay as an unfortunate victim of circumstances rather than as a reprehensibly greedy or foolish individual. Perhaps we simply care more about economic expansion, upward mobility, and security, all fueled by credit and bolstered by insurance, than we care about the moral obligation to keep one's promise. It remains to be seen whether movement toward systemic stabilization will develop as fully and will affect other areas of litigation as deeply as it seems to have affected debtor-creditor relations.

Nevertheless, the importance of systemic stabilization in shaping the role of the courts with respect to debt litigation undoubtedly has broader significance for the study of law and society. Social scientists and legal scholars have focused primarily on the mobilization and operation of governmental institutions established specifically for the adjudication or settlement of particular legal disputes, on the patterns of individual-case decisions or outcomes produced by those legal institutions, and on the origins of and justifications for legal rules intended to guide official decisions. While these topics are surely important, study after study tells us that the use of formal decision-making and enforcement processes tends to be extraordinary rather than ordinary. The extent and quality of the justice people experience depends equally, if not primarily, on the operation of nonlegal social and economic institutions that prevent, suppress, or settle most problems and on the broader social, economic, and political factors that affect the incidence and seriousness of harmful acts, accidents, deprivations, and disputes. What matters most is the frequency and intensity of problems worth fighting about. As in the case of debt collection, the incidence and severity of problems and the modes in which people deal with them will be affected by systemic political measures that encourage economic growth, stabilize markets (without unduly impairing efficiency and diversification), cushion and spread losses, and otherwise restructure those social conditions that are underlying causes of disputes. Understanding the facets of systemic stabilization, the forces that encourage and impede it, and its effects, negative as well as positive, as those relate to 
various areas of the law is an important agenda for students of legal systems.

\section{REFERENCES}

AMERICAN COLLECTORS ASSOCLATION (1980) Collectrends: A Fifteen Year Comparison, 1965-1980. Minneapolis: American Collectors Association.

ANDERSON, Roy R. (1975) "Coercive Collection and Exempt Property in Texas: A Debtor's Paradise or a Living Hell?" 13 Houston Law Review 84.

BARDACH, Eugene and Robert A. KAGAN (1982) Going By The Book: The Problem of Regulatory Unreasonableness. Philadelphia: Temple University Press. A Twentieth Century Fund Report.

BAUM, Lawrence, Sheldon GOLDMAN and Austin SARAT (1981-82) "The Evolution of Litigation in the Federal Courts of Appeals, 1895-1975," 16 Law \& Society Review 291

BENDER, Mark (1974) "The Long Term Growth of Consumer Installment Credit," 3 Consumer Credit Leader 6.

BENSTON, George J. (1977) "The Impact of Maturity Regulation on High Interest Rate Lenders and Borrowers," 41 Law and Contemporary Problems 180 (Autumn).

BLINDER, Alan S. (1980) "The Level and Distribution of Economic WellBeing," in M. Feldstein (ed.), The American Economy in Transition. Chicago: University of Chicago Press.

BONN, Robert L. (1972) "Arbitration: An Alternative System for Handling Contract Related Disputes," 17 Administrative Science Quarterly 254.

CALIFORNIA DEPARTMENT OF CORPORATIONS (1981) Annual Report for California Consumer Finance Laws.

CAPLOVITZ, David (1974) Consumers in Trouble: A Study of Debtors in Default. New York: The Free Press.

CHAMBERS, David L. (1979) Making Fathers Pay: The Enforcement of Child Support. Chicago: University of Chicago Press.

COLEMAN, Peter J. (1974) Debtors and Creditors in America: Insolvency, Imprisonment for Debt, and Bankruptcy, 1607-1900. Madison: State Historical Society of Wisconsin.

CONSUMER CREDIT LEADER (1973), Vol. 3, No. 1 (August).

EISENSTEIN, James and Herbert JACOB (1977) Felony Justice: An Organizational Analysis of Criminal Courts. Boston: Little Brown.

EPSTEIN, David G. (1980) Debtor-Creditor Law in a Nutshell, 2nd Ed. St. Paul: West Publishing Co.

EPSTEIN, David G. and Steve H. NICKLES (1981) Consumer Law in a Nutshell. St. Paul: West Publishing Co.

FELSTINER, William L. F. (1974) "Influences of Social Organization on Dispute Processing," 9 Law \& Society Review 63.

FELSTINER, William L. F., Richard L. ABEL and Austin SARAT (1980-81) "The Emergence and Transformation of Disputes: Naming, Blaming, Claiming . . ., "15 Law \& Society Review 631.

FRIEDMAN, Benjamin M. (1980) "Postwar Changes in the American Financial Markets," in M. Feldstein (ed.), The American Economy in Transition. Chicago: University of Chicago Press.

FRIEDMAN, Lawrence M. (1973) A History of American Law. New York: Simon and Schuster.

FRIEDMAN, Lawrence M. and Robert V. PERCIVAL (1976) "A Tale of Two Courts: Litigation in Alameda and San Benito Counties," 10 Law \& Society Review 267.

FRIEDMAN, Milton (1980) "The Changing Character of Financial Markets," in M. Feldstein (ed.), The American Economy in Transition Chicago: University of Chicago Press.

GELB, Joyce and Marian Lief PALLEY (1982) Women and Public Policies. Princeton: Princeton University Press.

GESSNER, Volkmar, Barbara RHODE, Gerhard STRATE and Klaus ZIEGERT (1978) "Three Functions of Bankruptcy Law: The West German Case," 12 Law \& Society Review 499. 
GOODWYN, Lawrence (1978) The Populist Moment: A Short History of the Agrarian Revolt in America. New York: Oxford University Press.

GRACE, J. Peter (1984) "Little Things Mean a Lot, Grace Panel Found," Wall Street Journal 24 (January 12).

GROSSMAN, Joel B., Herbert M. KRITZER, Kristen BUMILLER, Austin SARAT, Stephen McDOUGAL and Richard MULER (1982) "Dimensions of Institutional Participation: Who Uses the Courts, and How?" 44 Journal of Politics 86.

GUCCIONE, Eugene (1984) "Debt Cost is Soaking Up Cash Flow," Wall Street Journal 21 (January 13).

HISTORICAL STATISTICS OF THE UNITED STATES (1975). Washington, D.C.: U.S. Bureau of the Census.

JACKSON, Thomas H. (1982) "Bankruptcy, Non-Bankruptcy Entitlements, and the Creditors' Bargain," 91 Yale Law Journal 857.

JACOB, Herbert (1969) Debtors in Court: The Consumption of Government Services. Chicago: Rand McNally.

JENSEN, Merrill (1950) The New Nation: A History of the United States During the Confederation 1781-1789. New York: Alfred Knopf, Inc.

KAGAN, Richard L. (1981) Lawsuits and Litigants in Castile, 1500-1700. Chapel Hill: University of North Carolina Press.

KAGAN, Robert A., Bliss CARTWRIGHT, Lawrence M. FRIEDMAN and Stanton WHEELER (1977) "The Business of State Supreme Courts, 18701970," 30 Stanford Law Review 121.

(1978) "The Evolution of State Supreme Courts," 76 Michigan Law Review 961 .

KRISLOV, Samuel (1983) "Theoretical Perspectives on Case Load Studies: A Critique and a Beginning," in K. O. Boyum and L. Mather (eds.), Empirical Theories About Courts. New York: Longman.

LAURENT, Francis W. (1959) The Business of a Trial Court: 100 Years of Cases. Madison: University of Wisconsin Press.

LEFF, Arthur A. (1970) "Injury, Ignorance and Spite-The Dynamics of Coercive Collection," 80 Yale Law Journal 1.

MACAULAY, Stewart (1979) "Lawyers and Consumer Protection Laws," 14 Law \& Society Review 115.

MANN, Bruce H. (1980) "Rationality, Legal Change, and Community in Connecticut 1690-1760," 14 Law \& Society Review 187.

McDONALD, Forrest (1982) "The Constitution and Hamiltonian Capitalism," in R. A. Goldwin and W. A. Schambra (eds.), How Capitalistic Is the Constitution? Washington, D.C.: American Enterprise Institute.

McINTOSH, Wayne V. (1980-81) "150 Years of Litigation and Dispute Settlement: A Court Tale," 15 Law \& Society Review 823.

MECKLING, William H. (1977) "Financial Markets, Default, and Bankruptcy: The Role of the State," 41 Law and Contemporary Problems 13 (Autumn).

MICHELMAN, Irving S. (1966) Consumer Finance: $A$ Case History in American Business. New York: Frederick Fell, Inc.

MHLER, Merton H. (1977) "The Wealth Transfers of Bankruptcy: Some Illustrative Examples," 41 Law and Contemporary Problems 39 (Autumn).

MILLER, Richard E. and Austin SARAT (1981) "Grievances, Claims and Disputes: Assessing the Adversary Culture," 15 Law \& Society Review 525.

MOORE, Geoffrey H. and Philip A. KLEIN (1967) The Quality of Consumer Instalment Credit. New York: National Bureau of Economic Research and Columbia University Press.

MORTGAGE BANKERS ASSOCIATION OF AMERICA (1981) Seasonally Adjusted Delinquency and Foreclosure Ratios. Washington, D.C.

PAGTER, Carl R., Robert McCLOSKEY and Michael REINIS (1964) "The California Small Claims Court," 52 California Law Review 876.

PARENTI, Michael (1980) "The Constitution as an Elitist Document," in R. A. Goldwin and W.A. Schambra (eds.), How Democratic Is the Constitution? Washington, D.C.: American Enterprise Institute.

ROBERTSON, Ross M. and Gary M. WALTON (1979) History of the American Economy, 4th Ed. New York: Harcourt, Brace, Jovanovich.

ROBINSON, Roland I. (1980) "The Financing of Small Business in the United States," in S. W. Bruchey (ed.), Small Business in American Life. New York: Columbia University Press.

ROSS, H. Laurence (1970) Settled Out of Court: The Social Process of Insurance Claims Adjustments. Chicago: Aldine.

ROSS, H. Laurence and Neil O. LTTILEFIELD (1978) "Complaint As a Problem-Solving Mechanism," 12 Law \& Society Review 199. 
RUHNKA, John and Steven WELLER, with John A. MARTIN (1978) Small Claims Courts: A National Examination. Williamsburg, VA: National Center for State Courts.

SCHORR, Burt (1983) "States Cracking Down on Fathers Dodging ChildSupport Payments," Wall Street Journal 29 (January 26).

SHUCHMAN, Philip (1977) "Theory and Reality in Bankruptcy: The Spherical Chicken," 41 Law and Contemporary Problems 66 (Autumn).

SCHWARTZ, Alan (1983) "The Enforceability of Security Interests in Consumer Goods," 26 Journal of Law and Economics 117.

SHAPIRO, Martin (1975) "Courts," in F. Greenstein and N. Polsby (eds.), Handbook of Political Science, Vol. 5. Governmental Institutions and Processes. Reading, MA: Addison-Wesley.

SILVERMAN, Robert A. (1981) Law and Urban Growth: Civil Litigation in the Boston Trial Courts, 1880-1900. Princeton: Princeton University Press.

SMALL CLAIMS COURT STUDY GROUP (1972) Little Injustices: Small Claims Courts and the American Consumer. Washington, D.C.: The Center for Auto Safety.

STANLEY, David T. and Marjorie GIRTH (1971) Bankruptcy: Problem, Process, Reform. Washington, D.C.: Brookings Institution.

STARR, Roger (1979) "The End of Rental Housing?" 25 The Public Interest 57 (Fall).

SULLIVAN, George (1968) The Boom in Going Bust. New York: Macmillan.

U.S. COMMISSION ON THE BANKRUPTCY LAWS OF THE UNITED STATES (1973) Report. Washington, D.C.: U.S. Government Printing Office.

VUKOWICH, William T. (1974) "Debtors' Exemption Rights," 62 Georgetown Law Review 779.

WANNER, Craig (1974) "The Public Ordering of Private Relations, Part One: Initiating Civil Cases in Urban Trial Courts," 8 Law \& Society Review 421. (1975) "The Public Ordering of Private Relations, Part Two: Winning Civil Court Cases," 9 Law \& Society Review 293.

WHITFORD, William C. (1979) "A Critique of the Consumer Credit Collection System," 1979 Wisconsin Law Review 1047.

WOOD, Gordon S. (1969) The Creation of the American Republic, 1776-1787. Chapel Hill: University of North Carolina Press.

WRIGHT, Benjamin F., Jr. (1938) The Contract Clause of the Constitution. Cambridge, MA: Harvard University Press.

\section{CASES CITED}

Cass v. Gunnison, Administrator For Hewitt, 58 Michigan 108 (1885).

County v. Brock et al., 44 Michigan 45 (1880).

Cummings et al. $v$. Consolidated Mineral Water Co. and Industrial Trust Co., 27

Rhode Island 195 (1905).

First National Bank of Pocatello v. Bunting and Co., 7 Idaho 387 (1900).

Fuentes $v$. Shevin, 407 U.S. 67 (1972).

Home Building and Loan Association v. Blaisdell, 290 U.S. 398 (1934).

Lennon v. Parker, 22 Rhode Island 43 (1900).

Mitchell v. W. T. Grant Co., 416 U.S. 600 (1974).

North Georgia Finishing Inc. v. Di-chem Inc., 419 U.S. 601 (1975).

Pearce $v$. Maguire, 17 Rhode Island 61 (1890).

Ray $v$. Profett, 83 Tennessee 517 (1885).

St. Louis Hoop and Stove v. Dansforth and Wife, 160 Michigan 225 (1910).

Sniadach v. Family Finance Corp., 395 U.S. 337 (1964). 
HeinOnline -- 18 Law \& Soc'y Rev. 3721984 